\title{
Tropospheric chemistry in the Integrated Forecasting System of ECMWF
}

\author{
J. Flemming ${ }^{1}$, V. Huijnen ${ }^{2}$, J. Arteta ${ }^{3}$, P. Bechtold ${ }^{1}$, A. Beljaars ${ }^{1}$, A.-M. Blechschmidt ${ }^{4}$, M. Diamantakis ${ }^{1}$, \\ R. J. Engelen ${ }^{1}$, A. Gaudel ${ }^{5}$, A. Inness ${ }^{1}$, L. Jones ${ }^{1}$, B. Josse ${ }^{3}$, E. Katragkou ${ }^{6}$, V. Marecal ${ }^{3}$, V.-H. Peuch ${ }^{1}$, A. Richter ${ }^{4}$, \\ M. G. Schultz ${ }^{7}$, O. Stein ${ }^{7}$, and A. Tsikerdekis ${ }^{6}$ \\ ${ }^{1}$ European Centre for Medium-Range Weather Forecasts, Reading, UK \\ ${ }^{2}$ Royal Netherlands Meteorological Institute, De Belt, the Netherlands \\ ${ }^{3}$ Météo-France, Toulouse, France \\ ${ }^{4}$ Universität Bremen, Bremen, Germany \\ ${ }^{5}$ CNRS, Laboratoire d'Aérologie, UMR 5560, Toulouse, France \\ ${ }^{6}$ Department of Meteorology and Climatology, School of Geology, Aristotle University of Thessaloniki, Thessaloniki, Greece \\ ${ }^{7}$ Institute for Energy and Climate Research, Forschungszentrum Jülich, Jülich, Germany
}

Correspondence to: J. Flemming (johannes.flemming@ecmwf.int)

Received: 10 September 2014 - Published in Geosci. Model Dev. Discuss.: 18 November 2014

Revised: 3 March 2015 - Accepted: 12 March 2015 - Published: 7 April 2015

\begin{abstract}
A representation of atmospheric chemistry has been included in the Integrated Forecasting System (IFS) of the European Centre for Medium-Range Weather Forecasts (ECMWF). The new chemistry modules complement the aerosol modules of the IFS for atmospheric composition, which is named C-IFS. C-IFS for chemistry supersedes a coupled system in which chemical transport model (CTM) Model for OZone and Related chemical Tracers 3 was twoway coupled to the IFS (IFS-MOZART). This paper contains a description of the new on-line implementation, an evaluation with observations and a comparison of the performance of C-IFS with MOZART and with a re-analysis of atmospheric composition produced by IFS-MOZART within the Monitoring Atmospheric Composition and Climate (MACC) project. The chemical mechanism of C-IFS is an extended version of the Carbon Bond 2005 (CB05) chemical mechanism as implemented in CTM Transport Model 5 (TM5). CB05 describes tropospheric chemistry with 54 species and 126 reactions. Wet deposition and lightning nitrogen monoxide (NO) emissions are modelled in C-IFS using the detailed input of the IFS physics package. A 1 year simulation by C-IFS, MOZART and the MACC re-analysis is evaluated against ozonesondes, carbon monoxide $(\mathrm{CO})$ aircraft profiles, European surface observations of ozone $\left(\mathrm{O}_{3}\right), \mathrm{CO}$, sulfur dioxide $\left(\mathrm{SO}_{2}\right)$ and nitrogen dioxide $\left(\mathrm{NO}_{2}\right)$ as well as
\end{abstract}

satellite retrievals of $\mathrm{CO}$, tropospheric $\mathrm{NO}_{2}$ and formaldehyde. Anthropogenic emissions from the MACC/CityZen (MACCity) inventory and biomass burning emissions from the Global Fire Assimilation System (GFAS) data set were used in the simulations by both C-IFS and MOZART. CIFS (CB05) showed an improved performance with respect to MOZART for $\mathrm{CO}$, upper tropospheric $\mathrm{O}_{3}$, and wintertime $\mathrm{SO}_{2}$, and was of a similar accuracy for other evaluated species. C-IFS (CB05) is about 10 times more computationally efficient than IFS-MOZART.

\section{Introduction}

Monitoring and forecasting of global atmospheric composition are key objectives of the atmosphere service of the European Copernicus programme. The Copernicus Atmosphere Monitoring Service (CAMS) is based on combining satellite observations of atmospheric composition with stateof-the-art atmospheric modelling (Flemming et al., 2013; Hollingsworth et al., 2008). For that purpose, the Integrated Forecasting System (IFS) of the European Centre for Medium-Range Weather Forecasts (ECMWF) was extended for forecast and assimilation of atmospheric composition. Modules for aerosols (Morcrette et al., 2009; Benedetti et 
al., 2009) and greenhouse gases (Engelen et al., 2009) were integrated on-line in the IFS. Because of the complexity of the chemical mechanisms for reactive gases, modules for atmospheric chemistry were not initially included in the IFS. Instead, a coupled system (Flemming et al., 2009a) was developed, which couples the IFS to chemical transport model (CTM) Model for OZone and Related chemical Tracers 3 (MOZART, Kinnison et al., 2007) or Transport Model 5 (TM5, Huijnen et al., 2010) by means of the Ocean Atmosphere Sea Ice Soil (OASIS4) coupler software (Redler et al., 2010). Van Noije et al. (2014) coupled TM5 to IFS for climate applications in a similar approach. The coupled system made it possible to assimilate satellite retrievals of reactive gases with the assimilation algorithm of the IFS, which is also used for the assimilation of meteorological observations as well as for aerosol and greenhouse gases.

Coupled system IFS-MOZART has been successfully used for a re-analysis of atmospheric composition (Inness et al., 2013), pre-operational atmospheric composition forecasts (Stein et al., 2012), and forecast and assimilation of the stratospheric ozone $\left(\mathrm{O}_{3}\right)$ (Flemming et al., 2011; Lefever et al., 2014), tropospheric carbon monoxide (CO) (Elguindi et al., 2010) and $\mathrm{O}_{3}$ (Ordóñez et al., 2010). Coupled system IFS-TM5 has been used in a case study on a period with intense biomass burning in Russia in 2010 (Huijnen et al., 2012). Nevertheless, the coupled approach has limitations such as the need for interpolation between the IFS and CTM model grids and the duplicate simulation of transport processes. Furthermore, its computational performance is often not optimal as it can suffer from load imbalances between the coupled components.

Consequently, modules for atmospheric chemistry and related physical processes have now been integrated on-line in the IFS, thereby complementing the on-line integration strategy already pursued for aerosol and greenhouse gases in IFS. The IFS including modules for atmospheric composition is named Composition-IFS (C-IFS). C-IFS makes it possible (i) to use the detailed meteorological simulation of the IFS for the simulation of the fate of constituents (ii) to use the IFS data assimilation system to assimilate observations of atmospheric composition and (iii) to simulate feedback processes between atmospheric composition and weather. A further advantage of C-IFS is the possibility of model runs at a high horizontal and vertical resolution because of the high computational efficiency of C-IFS. C-IFS is the global model system run in pre-operational mode as part of the Monitoring Atmospheric Composition and Climate - Interim Implementation project (MACC II and MACC III) in preparation of CAMS.

Including chemistry modules in general circulation models $(\mathrm{GCM})$ to simulate interaction of stratospheric $\mathrm{O}_{3}$ (e.g. Steil et al., 1998) and aerosols (e.g. Haywood et al., 1997) in the climate system started in the mid-1990s. Later, more comprehensive schemes for tropospheric chemistry were included in climate GCM such as ECHAM5-HAMMOZ (Poz- zoli et al., 2008; Rast et al., 2014) and CAM-chem (Lamarque et al., 2012) to study short-lived greenhouse gases and the influence of climate change on air pollution (e.g. Fiore et al., 2012). In the UK Met Office's Unified Model (UM), stratospheric chemistry (Morgenstern et al., 2009) and tropospheric chemistry (O'Connor et al., 2014) can be simulated together with the GLOMAP mode aerosol scheme (Mann et al., 2010). Examples of the on-line integration of chemistry modules in global circulation models with focus on NWP are GEM-AQ (Kaminski et al., 2008), GEMS-BACH (Ménard et al., 2007) and GU-WRF/Chem (Zhang et al., 2012). Savage et al. (2013) evaluate the performance of air quality forecast with the UM on the regional scale. Baklanov et al. (2014) give a comprehensive overview of on-line coupled chemistry-meteorological models for regional applications.

C-IFS is intended to run with several chemistry schemes for both the troposphere and the stratosphere in the future. Currently, only the tropospheric chemical mechanism CB05 originating from the TM5 CTM (Huijnen et al., 2010) has been thoroughly tested. For example, C-IFS (CB05) has been applied to study the $\mathrm{HO}_{2}$ uptake on clouds and aerosols (Huijnen et al., 2014) and pollution in the Arctic (Emmons et al., 2014). The tropospheric and stratospheric scheme RACMOBUS of the MOCAGE model (Bousserez et al., 2007) and the MOZART 3 chemical scheme as well as an extension of the CB05 scheme with the stratospheric chemical mechanism of the BASCOE model (Errera et al., 2008) have been technically implemented and are being scientifically tested. Only C-IFS (CB05) is the subject of this paper.

Each chemistry scheme in C-IFS consists of the specific gas-phase chemical mechanism, multi-phase chemistry, the calculation of photolysis rates and upper chemical boundary conditions. Dry and wet deposition, emission injection and parameterisation of lightning NO emissions as well as transport and diffusion are simulated by the same approach for all chemistry schemes. Likewise, emissions and dry deposition input data are kept the same for all configurations.

The purpose of this paper is to document C-IFS and to present its model performance with respect to observations. Since C-IFS (CB05) replaced the current operational MACC model system for reactive gases (IFS-MOZART) both in data assimilation and forecast mode, the evaluation in this paper is carried out predominantly with observations that are used for the routine evaluation of the MACC II system. The model results are compared (i) with a MOZART stand-alone simulation, which is equivalent to a IFS-MOZART simulation, and (ii) with the MACC re-analysis (Inness et al., 2013), which is an application of IFS-MOZART in data assimilation mode. All model configurations used the same emission data. The comparison demonstrates that C-IFS is ready to be used operationally.

The paper is structured as follows. Section 2 is a description of the C-IFS, with the focus on the newly implemented physical parameterisations and the CB05 chemical mechanism. Section 3 contains the evaluation with observations 
of a 1 year simulation with C-IFS (CB05) and a comparison with the results from the MOZART run and the MACC re-analysis. The paper is concluded with a summary and an outlook in Sect. 4.

\section{Description of C-IFS}

\subsection{Overview of C-IFS}

The IFS consists of a spectral NWP model that applies the semi-Lagrangian (SL) semi-implicit method to solve the governing dynamical equations. The simulation of the hydrological cycle includes prognostic representations of cloud fraction, cloud liquid water, cloud ice, rain and snow (Forbes et al., 2011). The simulations presented in this paper used the IFS release CY40r1. The technical and scientific documentation of this IFS release can be found at http: //www.ecmwf.int/en/forecasts/documentation-and-support/ changes-ecmwf-model/cy40r1-summary/cycle-40r1.

Changes in the operational model are documented at https:// software.ecmwf.int/wiki/display/IFS/Operational+changes.

At the start of the time step, the three-dimensional advection of the tracers mass mixing ratios is simulated by the SL method as described in Temperton et al. (2001) and Hortal (2002). Next, the tracers are vertically distributed by the diffusion scheme (Beljaars and Viterbo, 1998) and by convective mass fluxes (Bechtold et al., 2014). The diffusion scheme also simulates the injection of emissions and the loss by dry deposition (see Sect. 2.4.1). The output of the convection scheme is used to calculate NO production by lightning (see Sect. 2.4.3). Finally, the sink and source terms due to chemical conversion (see Sect. 2.5), wet deposition (see Sect. 2.4.2) and prescribed surface and stratospheric boundary conditions are calculated (see Sect. 2.5.2).

The chemical species and the related processes are represented only in grid-point space. The horizontal grid is a reduced Gaussian grid (Hortal and Simmons, 1991). C-IFS can be run at varying vertical and horizontal resolutions. The simulations presented in this paper were carried out at a T255 spectral resolution (i.e. truncation at wave number 255), which corresponds to a grid box size of about $80 \mathrm{~km}$. The vertical discretisation uses 60 levels up to the model top at $0.1 \mathrm{hPa}(65 \mathrm{~km})$ in a hybrid sigma-pressure coordinate. The vertical extent of the lowest level is about $17 \mathrm{~m}$; it is $100 \mathrm{~m}$ at about $300 \mathrm{~m}$ above ground, $400-600 \mathrm{~m}$ in the middle troposphere and about $800 \mathrm{~m}$ at about $10 \mathrm{~km}$ in height.

The modus operandi of C-IFS is one of a forecast model in a NWP framework. The simulations of C-IFS are a sequence of daily forecasts over a period of several days. Each forecast is initialised by the ECMWF's operational analysis for the meteorological fields and by the 3-D chemistry fields from the previous forecast ("forecast mode"). Continuous simulations over longer periods are carried out in "relaxation mode". In relaxation mode the meteorological fields are relaxed to the fields of a meteorological re-analysis, such as ERA-Interim, during the run (Jung et al., 2008) to ensure realistic and consistent meteorological fields.

\subsection{Transport}

The transport by advection, convection and turbulent diffusion of the chemical tracers uses the same algorithms as developed for the transport of water vapour in the NWP applications of IFS. The advection is simulated with a threedimensional semi-Lagrangian advection scheme, which applies a quasi-monotonic cubic interpolation of the departure values. Since the semi-Lagrangian advection does not formally conserve mass, a global mass fixer is applied. The effect of different global mass fixers is discussed in Diamantakis and Flemming (2014) and Flemming and Huijnen (2011). A proportional mass fixer was used for the runs presented in this paper because of the overall best balance between the results and computational cost.

The vertical turbulent transport in the boundary layer is represented by a first-order K-diffusion closure. The surface emissions are injected as lower boundary flux in the diffusion scheme. The lower boundary flux condition also accounts for the dry deposition flux based on the projected surface mass mixing ratio in an implicit way. The vertical transport by convection is simulated as part of the cumulus convection. It applies a bulk mass flux scheme which was originally described in Tiedtke (1989). The scheme considers deep, shallow and mid-level convection. Clouds are represented by a single pair of entraining/detraining plumes which determine the updraught and downdraught mass fluxes (http://old. ecmwf.int/research/ifsdocs/CY40r1/ in Physical Processes, Chapter 6, pp. 73-90). Highly soluble species such as nitric acid $\left(\mathrm{HNO}_{3}\right)$, hydrogen peroxide $\left(\mathrm{H}_{2} \mathrm{O}_{2}\right)$ and aerosol precursors are assumed to be scavenged in the convective rain droplets and are therefore excluded from the convective mass transfer.

The operator splitting between the transport and the sink and source terms follows the implementation for water vapour (Beljaars et al., 2004). Advection, diffusion and convection are simulated sequentially. The sink and source processes are simulated in parallel using an intermediate update of the mass mixing ratios with all transport tendencies. At the end of the time step tendencies from transport and sink and source terms are added together for the final update the concentration fields. Resulting negative mass mixing ratios are corrected at this point by setting the updated mass mixing ratio to a "chemical zero" of $1.0 \times 10^{-25} \mathrm{~kg} \mathrm{~kg}^{-1}$. For the majority of the species the contribution of the negative fixer was below $0.1 \%$ of the dominating source or sink term. The contribution was of the order of $1 \%$ for nitrogen species such as $\mathrm{NO}, \mathrm{N}_{2} \mathrm{O}_{5}$ as well as up to $3 \%$ for highly soluble species such $\mathrm{HNO}_{3}, \mathrm{HO}_{2}, \mathrm{NO}_{3}$ A. Large gradients of $\mathrm{NO}_{\mathrm{x}}$ at the terminator in the stratosphere as well as intensive wet 
Table 1. Annual emissions from anthropogenic, biogenic and natural sources and biomass burning for 2008 in Tg for a C-IFS (CB05) run at $\mathrm{T} 255$ resolution. Anthropogenic NO emissions contain a contribution of $1.8 \mathrm{Tg}$ aircraft emissions and $12.3 \mathrm{Tg}(5.7 \mathrm{Tg} \mathrm{N})$ lightning emissions (LiNO) is added in the biomass burning columns.

\begin{tabular}{lccc}
\hline Species & Anthropogenic & Biogenic and natural & Biomass burning \\
\hline $\mathrm{CO}$ & 584 & 96 & 328 \\
$\mathrm{NO}$ & $70+1.8$ & 10 & $9.2+12.3$ (LiNO) \\
$\mathrm{HCHO}$ & 3.4 & 4.0 & 4.9 \\
$\mathrm{CH}_{3} \mathrm{OH}$ & 2.2 & 159 & 8.5 \\
$\mathrm{C}_{2} \mathrm{H}_{6}$ & 3.4 & 1.1 & 2.3 \\
$\mathrm{C}_{2} \mathrm{H}_{5} \mathrm{OH}$ & 3.1 & 0 & 0 \\
$\mathrm{C}_{2} \mathrm{H}_{4}$ & 7.7 & 18 & 4.3 \\
$\mathrm{C}_{3} \mathrm{H}_{8}$ & 4.0 & 1.3 & 1.2 \\
$\mathrm{C}_{3} \mathrm{H}_{6}$ & 3.5 & 7.6 & 2.5 \\
$\mathrm{Parafins}_{\mathrm{TgC}}$ & 31 & 18 & 1.7 \\
Olefines $(\mathrm{TgC})$ & 2.4 & 0 & 0.7 \\
$\mathrm{Aldehydes}(\mathrm{TgC})$ & 1.1 & 6.1 & 2.1 \\
$\mathrm{CH}_{3} \mathrm{COCH}$ & 1.3 & 28 & 2.4 \\
Isoprene & 0 & 523 & 0 \\
Terpenes & 0 & 97 & 0 \\
$\mathrm{SO}_{2}$ & 98 & 9 & 2.2 \\
$\mathrm{DMS}_{\mathrm{NH}}$ & 0 & 38 & 0.2 \\
$\mathrm{NH}_{3}$ & 40 & 11 & 6.2 \\
\hline
\end{tabular}

deposition were the reasons for the increased occurrence of projected negative concentrations.

\subsection{Emissions for 2008}

The anthropogenic surface emissions were given by the MACCity inventory (Granier et al., 2011) and aircraft NO emissions of a total of $\sim 0.8 \mathrm{Tg} \mathrm{Nyr}^{-1}$ were applied (Lamarque et al., 2010). Natural emissions from soils and oceans were taken from the Precursors of Ozone and their Effects in the Troposphere (POET) database for 2000 (Granier et al., 2005; Olivier et al., 2003). The biogenic emissions were simulated off-line by the MEGAN2.1 model (Guenther et al., 2006). The anthropogenic and natural emissions were used as monthly means without accounting for the diurnal cycle. Daily biomass burning emissions were produced by the Global Fire Assimilation System (GFAS) version 1, which is based on satellite retrievals of fire radiative power (Kaiser et al., 2012). The actual emission totals used in the T255 simulation for 2008 from anthropogenic and biogenic sources and biomass burning as well as lighting NO are given in Table 1 .

\subsection{Physical parameterisations of sources and sinks}

\subsubsection{Dry deposition}

Dry deposition is an important removal mechanism at the surface in the absence of precipitation. It depends on the diffusion close to the earth surface, the properties of the constituent and on the characteristics of the surface, in particular the type and state of the vegetation and the presence of inter- cepted rain water. Dry deposition plays an important role in the biogeochemical cycles of nitrogen and sulfur, and it is a major loss process of tropospheric $\mathrm{O}_{3}$. Modelling the dry deposition fluxes in C-IFS is based on a resistance model (Wesely, 1989), which differentiates the aerodynamic, the quasilaminar and the canopy or surface resistance. The inverse of the total resistance is equivalent to a dry deposition velocity $V_{\mathrm{D}}$.

The dry deposition flux $F_{\mathrm{D}}$ at the model surface is calculated based on the dry deposition velocity $V_{\mathrm{D}}$, the mass mixing ratio $X_{s}$ and air density $\rho_{s}$ at the lowest model level $s$, in the following way:

$F_{\mathrm{D}}=V_{\mathrm{D}} X_{s} \rho_{s}$.

The calculation of the loss by dry deposition has to account for the implicit character of the dry deposition flux since it depends on the mass mixing ratio $X_{s}$.

The dry deposition velocities were calculated as monthly mean values from a 1 year simulation using the approach described in Michou et al. (2004). It used meteorological and surface input data such as wind speed, temperature, surface roughness and soil wetness from the ERA-Interim data set. At the surface the scheme makes a distinction between uptake resistances for vegetation, bare soil, water, snow and ice. The surface and vegetation resistances for the different species are calculated using the stomatal resistance of water vapour. The stomatal resistance for water vapour is calculated depending on the leaf area index, radiation and the soil wetness at the uppermost surface layer. Together with the cuticular and mesophyllic resistances this is combined into the leaf resistance according to Wesely (1989) using season and 
surface type specific parameters as referenced in Seinfeld and Pandis (1998).

Dry deposition velocities have higher values during the day because of lower aerodynamic resistance and canopy resistance. Zhang et al. (2003) reported that averaged observed $\mathrm{O}_{3}$ and sulfur dioxide $\left(\mathrm{SO}_{2}\right)$ dry deposition velocities can be up to 4 times higher at day time than at night time. As this important variation is not captured with the monthly mean dry deposition values, a $\pm 50 \%$ variation is imposed on all dry deposition values based on the cosine of the solar zenith angle. This modulation tends to decrease dry deposition for species with a night-time maximum at the lowest model level, and it increases dry deposition of $\mathrm{O}_{3}$.

Table A4 (Supplement) contains annual total loss by dry deposition and is expressed as a lifetime estimate by dividing by tropospheric burden for a simulation using monthly dry deposition values for 2008. Dry deposition was most effective for many species, in particular $\mathrm{SO}_{2}$ and ammonia $\left(\mathrm{NH}_{3}\right)$, as the respective lifetimes were 1 day to 1 week. For tropospheric $\mathrm{O}_{3}$, the respective globally averaged timescale is about 3 months. Because dry deposition occurs mainly over ice-free land surfaces, the corresponding timescale is at least 3 times shorter in these areas.

\subsubsection{Wet deposition}

Wet deposition is the transport and removal of soluble or scavenged constituents by precipitation. It includes the following processes.

- In-cloud scavenging and removal by rain and snow (rain-out).

- Release by evaporation of rain and snow.

- Below cloud scavenging by precipitation falling through without formation of precipitation (wash out).

It is important to take the sub-grid scale of cloud and precipitation formation into account for the simulation of wet deposition. The IFS cloud scheme provides information on the cloud and the precipitation fraction for each grid box. It uses a random overlap assumption (Jakob and Klein, 2000) to derive cloud and precipitation area fraction. The same method has been used by Neu and Prather (2012), who demonstrated the importance of the overlap assumption for the simulation of the wet deposition. The precipitation fluxes for the simulation of wet removal in C-IFS were scaled to be valid over the precipitation fraction of the respective grid box. The loss of tracer by rain-out and wash-out was limited to the area of the grid box covered by precipitation. Likewise, the cloud water and ice content is scaled to the respective cloud area fraction. If the sub-grid-scale distribution was not considered in this way, wet deposition was lower for highly soluble species such as $\mathrm{HNO}_{3}$ because the species is only removed from the cloudy or rainy grid box fraction. For species with low solu- bility the wet deposition loss was slightly decreased because of the decrease in effective cloud and rain water.

Even if wet deposition removes tracer mass only in the precipitation area, the mass mixing ratio representing the entire grid box is changed accordingly after each model time step. This is equivalent to the assumption that there is instantaneous mixing within the grid box on the timescale of the model time step. As discussed in Huijnen et al. (2014), this assumption may lead to an overestimation of the simulated tracer loss.

The module for wet deposition in C-IFS is based on the Harvard wet deposition scheme (Jacob et al., 2000; Liu et al., 2001). In contrast to Jacob et al. (2000), tracers scavenged in wet convective updrafts are not removed as part of the convection scheme. Nevertheless, the fraction of highly soluble tracers in cloud condensate is simulated to limit the amount of tracers lifted upwards, as only the gas-phase fraction is transported by the mass flux. The removal by convective precipitation is simulated in the same way as for large-scale precipitation in the wet deposition routine.

The input fields to the wet deposition routine are the following prognostic variables, calculated by the IFS cloud scheme (Forbes et al., 2011): total cloud and ice water content, grid-scale rain and snow water content and cloud and grid-scale precipitation fraction as well as the derived fluxes for convective and grid-scale precipitation fluxes at the grid cell interfaces. For convective precipitation, a precipitation fraction of 0.05 is assumed and the convective rain and snow water content is calculated assuming a droplet fall speed of $5 \mathrm{~ms}^{-1}$.

Wash-out, evaporation and rain-out are calculated after each other for large-scale and convective precipitation. The amount of trace gas dissolved in cloud droplets is calculated using Henrys law equilibrium or assuming that $70 \%$ of aerosol precursors such as sulfate $\left(\mathrm{SO}_{4}\right), \mathrm{NH}_{3}$ and nitrate $\left(\mathrm{NO}_{3}\right)$ is dissolved in the droplet. The effective Henry coefficient for $\mathrm{SO}_{2}$, which accounts for the dissociation of $\mathrm{SO}_{2}$, is calculated following Seinfeld and Pandis (1998, p. 350). The other Henry's law coefficients are taken from the compilation by Sander (1999) (www.henrys-law.org, Table A1 in the Supplement).

The loss by rain-out is determined by the precipitation formation rate. The retention coefficient $R$, which accounts for the retention of dissolved gas in the liquid cloud condensate as it is converted to precipitation, is 1.0 for all species in warm clouds $(T>268 \mathrm{~K})$. For mixed clouds $(T<268 \mathrm{~K})$, $R$ is 0.02 for all species but 1.0 for $\mathrm{HNO}_{3}$ and 0.6 for $\mathrm{H}_{2} \mathrm{O}_{2}$ (von Blohn, 2011). In ice clouds only, $\mathrm{H}_{2} \mathrm{O}_{2}$ (Lawrence and Crutzen, 1998) and $\mathrm{HNO}_{3}$ are scavenged.

Partial evaporation of the precipitation fluxes leads to the release of $50 \%$ of the resolved tracer and $100 \%$ in the case of total evaporation (Jacob et al., 2000). Wash-out is either mass-transfer or Henry-equilibrium limited. $\mathrm{HNO}_{3}$, aerosol precursors and other highly soluble gases are washed out using a first-order wash-out rate of $0.1 \mathrm{~mm}^{-1}$ (Levine and 
Schwartz, 1982) to account for the mass transfer. For less soluble gases, the resolved fraction in the rain water is calculated assuming Henry equilibrium in the evaporated precipitation.

Table A5 (Supplement) contains total loss by wet deposition and is expressed as a timescale in days based on the tropospheric burden. For aerosol precursors nitrate, sulfate and ammonium, $\mathrm{HNO}_{3}$ and $\mathrm{H}_{2} \mathrm{O}_{2}$ wet deposition is the most important loss process, with respective timescales of $2-4$ days.

\subsubsection{NO emissions from lightning}

NO emissions from lightning are a considerable contribution to the global atmospheric $\mathrm{NO}_{\mathrm{x}}$ budget. Estimates of the global annual source vary between 2 and $8 \mathrm{TgNyr}^{-1}$ (Schumann and Huntrieser, 2007). $5 \mathrm{Tg} \mathrm{Nyr}^{-1}$ (10.7 $\mathrm{TgNOyr}^{-1}$ ) is the most commonly assumed value for global CTMs, which is about 6-7 times the value of NO emissions from aircraft (Gauss et al., 2006), or $17 \%$ of the total anthropogenic emissions. NO emissions from lightning play an important role in the chemistry of the atmosphere because they are released in the rather clean air of the free troposphere, where they can influence the $\mathrm{O}_{3}$ budget and hence the $\mathrm{OH}-\mathrm{HO}_{2}$ partitioning (DeCaria et al., 2005).

The parameterisation of the lightning NO production in CIFS consists of estimates of (i) the flash rate density, (ii) the flash energy release and (iii) the vertical emission profile for each model grid column. The estimate of the flash-rate density is based on parameters of the convection scheme. The CIFS has two options to simulate the flash-rate densities using the following input parameters: (i) convective cloud height (Price and Rind, 1992) or (ii) convective precipitation (Meijer et al., 2001).

The parameterisations distinguish between land and ocean points by assuming about 5-10 times higher flash rates over land. Additional checks on cloud base height, cloud extent and temperature are implemented to select only clouds that are likely to generate lightning strokes. The coefficients of the two parameterisations were derived from field studies and depend on the model resolution. With the current implementation of C-IFS (T255L60), the global flash rates were 26 and 43 flashes per second for the schemes by Price and Rind (1992) and Meijer et al. (2001), respectively. It seemed therefore necessary to scale the coefficients to get a flash rate in the range of the observed values of about 40-50 flashes per second derived from observations of the Optical Transient Detector (OTD) and the Lightning Imaging Sensor (LIS) (Cecil et al., 2012). Figure 1 shows the annual flash rate density simulated by the two parameterisations together with observations from the LIS/OTD data set. The two approaches show the main flash activity in the tropics, but there were differences in the distributions over land and sea. The smaller land-sea differences of Meijer et al. (2001) agreed better with the observations. The observed maximum over central Africa was well reproduced by both parameterisations, but the schemes produce an exaggerated maximum over tropical South America. The lightning activity over the United States was underestimated by both parameterisations. The parameterisation by Meijer et al. (2001) has been used for the C-IFS runs presented in this paper.

Cloud to ground (CG) and cloud to cloud (CC) flashes are assumed to release a different amount of energy, which is proportional to the NO release. Price et al. (1997) suggest that the energy release of CG is 10 times higher. However, more recent studies suggest a similar value for CG and CC energy release based on aircraft observations and model studies (Ott et al., 2010), which is followed in C-IFS. In C-IFS, CG and CC fractions are calculated using the approach by Price and Rind (1993), which is based on a fourth-order function of cloud height above freezing level.

The vertical distribution of the NO release is of importance for its impact on atmospheric chemistry. Many CTMs use the suggestion of Pickering et al. (1998) of a C-shape profile, which peaks at the surface and in the upper troposphere. Ott et al. (2010) suggest a "backward C-shape" profile which locates most of the emission in the middle of the troposphere. The vertical distribution can be simulated by CIFS (i) according to Ott et al. (2010) or (ii) as a C-shape profile following Huijnen et al. (2010). The approach by Ott et al. (2010) is used in the simulation presented here. As lightning NO emissions occur mostly in situations with strong convective transport, differences in the injection profile had little impact.

As the lightning emissions depend on the convective activity, they change at different resolutions or after changes to the convection scheme. The C-IFS lightning emissions, using the parameterisation of Meijer et al. (2001) based on convective precipitation, were $4.9 \mathrm{Tg} \mathrm{Nyr}^{-1}$ at $\mathrm{T} 159$ resolution and $5.7 \mathrm{Tg} \mathrm{Nyr}^{-1}$ at $\mathrm{T} 255$ resolution.

\subsection{CB05 chemistry scheme}

\subsubsection{Gas-phase chemistry}

The chemical mechanism is a modified version of the Carbon Bond mechanism 5 (CB05, Yarwood et al., 2005), which is originally based on the work of Gery et al. (1989) with added reactions from Zaveri and Peters (1999) and from Houweling et al. (1998) for isoprene. The CB05 scheme adopts a lumping approach for organic species by defining a separate tracer species for specific types of functional groups. The speciation of the explicit species into lumped species follows the recommendations given in Yarwood et al. (2005). The CB05 scheme used in C-IFS has been further extended in the following way: An explicit treatment of methanol $\left(\mathrm{CH}_{3} \mathrm{OH}\right)$, ethane $\left(\mathrm{C}_{2} \mathrm{H}_{6}\right)$, propane $\left(\mathrm{C}_{3} \mathrm{H}_{8}\right)$, propene $\left(\mathrm{C}_{3} \mathrm{H}_{6}\right)$ and acetone $\left(\mathrm{CH}_{3} \mathrm{COCH}_{3}\right)$ has been introduced as described in Williams et al. (2013). The isoprene oxidation has been modified motivated by Archibald et al. (2010). Higher $C_{3}$ peroxy radi- 

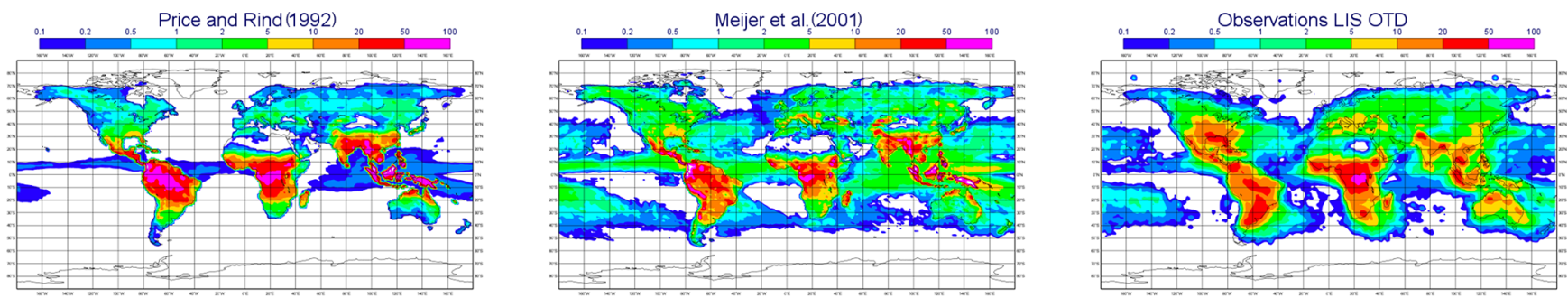

Figure 1. Flash density in flashes $\left(\mathrm{km}^{-2} \mathrm{yr}^{-1}\right)$ from the IFS input data using the parameterisation by Price and Rind (1992) (left), Meijer et al. (2001) (middle) and observations from the LIS OTD database (right). All fields were scaled to an annual flash density of $46 \mathrm{fl} \mathrm{s}{ }^{-1}$.

cals formed during the oxidation of $\mathrm{C}_{3} \mathrm{H}_{6}$ and $\mathrm{C}_{3} \mathrm{H}_{8}$ were included following Emmons et al. (2010).

The CB05 scheme is supplemented with chemical reactions for the oxidation of $\mathrm{SO}_{2}$, di-methyl sulfide (DMS), methyl sulfonic acid (MSA) and $\mathrm{NH}_{3}$, as outlined in Huijnen et al. (2014). For the oxidation of DMS, the approach of Chin et al. (1996) is adopted. Table A1 (Supplement) gives a comprehensive list of the trace gases included in the chemical scheme.

The reaction rates have been updated according to the recommendations given in either Sander et al. (2011) or Atkinson et al. $(2004,2006)$. The oxidation of CO by the hydroxyl radical $(\mathrm{OH})$ implicitly accounts for the formation and subsequent decomposition of the intermediate species HOCO as outlined in Sander et al. (2006). For lumped species, e.g. ALD2, the reaction rate is determined by an average of the rates of reaction for the most abundant species, e.g. $\mathrm{C} 2$ and $\mathrm{C} 3$ aldehydes, in that group. An overview of all gas-phase reactions and reaction rates as applied in this version of C-IFS can be found in Table A2 (Supplement).

For the loss of trace gases by heterogeneous oxidation processes, the model explicitly accounts for the oxidation of $\mathrm{SO}_{2}$ in cloud through aqueous-phase reactions with $\mathrm{H}_{2} \mathrm{O}_{2}$ and $\mathrm{O}_{3}$, depending on the acidity of the solution. The $\mathrm{pH}$ is computed from the $\mathrm{SO}_{4}, \mathrm{MSA}, \mathrm{HNO}_{3}, \mathrm{NO}_{3} \mathrm{~A}, \mathrm{NH}_{3}$ and $\mathrm{NH}_{4}$ concentrations, as well as from a climatological $\mathrm{CO}_{2}$ value. The $\mathrm{pH}$, in combination with the Henry coefficient, defines the fraction of sulfate residing in the aqueous phase, compared to the gas-phase concentration (Dentener and Crutzen, 1993). The heterogeneous conversion of $\mathrm{N}_{2} \mathrm{O}_{5}$ into $\mathrm{HNO}_{3}$ on cloud droplets and aerosol particles is applied with a reaction probability $(\gamma)$ set to 0.02 (Evans and Jacob, 2005). The surface area density is computed based on a climatological aerosol size distribution function, applied to the $\mathrm{SO}_{4}$, MSA and $\mathrm{NO}_{3} \_\mathrm{A}$ aerosol, as well as to clouds assuming a droplet size of $8 \mu \mathrm{m}$.

\subsubsection{Photolysis rates}

For the calculation of photo-dissociation rates, an on-line parameterisation for the derivation of actinic fluxes is used (Williams et al., 2012). It applies a modified band approach
(MBA), which is an updated version of the work by Landgraf and Crutzen (1998), tailored and optimised for use in tropospheric CTMs. The approach uses seven absorption bands across the spectral range 202-695 nm. At instances of large solar zenith angles $\left(71-85^{\circ}\right)$, a different set of band intervals is used. In the MBA, the radiative transfer calculation using the absorption and scattering components introduced by gases, aerosols and clouds is computed on-line for each of seven pre-defined band intervals based on the two-stream solver of Zdunkowski et al. (1980).

The optical depth of clouds is calculated based on a parameterisation available in IFS (Slingo, 1989; Fu et al., 1998) for the cloud optical thickness at $550 \mathrm{~nm}$. For the simulation of the impact of aerosols on the photolysis rates, a climatological field for aerosols is used, as detailed in Williams et al. (2012). There is also an option to use the MACC aerosol fields.

In total, 20 photolysis rates are included in the scheme, as given in Table A3 (Supplement). The explicit nature of the MBA implies a good flexibility in terms of updating molecular absorption properties (cross sections and quantum yields) and the addition of new photolysis rates into the model.

\subsubsection{The chemical solver}

The chemical solver used in C-IFS (CB05) is an Euler backward iterative (EBI) solver (Hertel et al., 1993). This solver was originally designed for use with the CBM4 mechanism of Gery et al. (1989). The chemical time step is $22.5 \mathrm{~min}$, which is half of the dynamical model time step of $45 \mathrm{~min}$ at T255 resolution. Eight, four or one iterations are carried out for fast-, medium- and slow-reacting chemical species to obtain a solution. The number of iterations is doubled in the lowest four model levels, where the perturbations due to emissions can be large.

\subsubsection{Stratospheric boundary conditions}

The modified CB05 chemical mechanism includes no halogenated species and no photolytic destruction below $202 \mathrm{~nm}$, and is therefore not suited for the description of stratospheric chemistry. Thus, realistic upper boundary conditions for the longer-lived gases such as $\mathrm{O}_{3}$, methane $\left(\mathrm{CH}_{4}\right)$, and $\mathrm{HNO}_{3}$ are 
needed to capture the influence of stratospheric intrusions on the composition of the upper troposphere.

Stratospheric $\mathrm{O}_{3}$ chemistry in C-IFS (CB05) is parameterised by the Cariolle scheme (Cariolle and Teyssèdre, 2007). Chemical tendencies for stratospheric and tropospheric $\mathrm{O}_{3}$ are merged at an empirical interface of the diagnosed tropopause height in IFS. Additionally, stratospheric $\mathrm{O}_{3}$ in C-IFS can be nudged to $\mathrm{O}_{3}$ analyses of either the MACC re-analysis (Inness et al., 2013) or ERA-Interim (Dee et al., 2011). The tropopause height in IFS is diagnosed either from the gradient in humidity or the vertical temperature gradient.

Stratospheric $\mathrm{HNO}_{3}$ at $10 \mathrm{hPa}$ is controlled by a climatology of $\mathrm{HNO}_{3}$ and $\mathrm{O}_{3}$ observations from the Microwave Limb Sounder (MLS) aboard the Upper Atmosphere Research satellite (UARS). $\mathrm{HNO}_{3}$ is set to according to the observed $\mathrm{HNO}_{3}-\mathrm{O}_{3}$ ratio and the simulated $\mathrm{O}_{3}$ concentrations. Furthermore, stratospheric $\mathrm{CH}_{4}$ is constrained by a climatology based on observations of the Halogen Occultation Experiment instrument (Grooß and Russel, 2005), at 45 and at $90 \mathrm{hPa}$ in the extra-tropics, which implicitly accounts for the stratospheric chemical loss of $\mathrm{CH}_{4}$ by $\mathrm{OH}$, chlorine $(\mathrm{Cl})$ and oxygen $\left(\mathrm{O}^{1} \mathrm{D}\right)$ radicals. It should be noted that the surface concentrations of $\mathrm{CH}_{4}$ are also fixed in this configuration of the model.

\subsubsection{Gas-aerosol partitioning}

Gas-aerosol partitioning is calculated using the Equilibrium Simplified Aerosol Model (EQSAM, Metzger et al., 2002a, b). The scheme has been simplified so that only the partitioning between $\mathrm{HNO}_{3}$ and the nitrate aerosol $\left(\mathrm{NO}_{3}^{-}\right)$and between $\mathrm{NH}_{3}$ and the ammonium aerosol $\left(\mathrm{NH}_{4}^{+}\right)$is calculated. $\mathrm{SO}_{4}^{2-}$ is assumed to remain completely in the aerosol phase because of its very low vapour pressure. The assumptions of the equilibrium model are that (i) aerosols are internally mixed and obey thermodynamic gas-aerosol equilibrium and that (ii) the water activity of an aqueous aerosol particle is equal to the ambient relative humidity (RH). Furthermore, the aerosol water mainly depends on the aerosol mass and the type of the solute, so that parameterisations of single solute molalities and activity coefficients can be defined, depending only on the type of the solute and RH. The advantage of using such parameterisations is that the entire aerosol equilibrium composition can be solved analytically. For atmospheric aerosols in thermodynamic equilibrium with the ambient RH, the following reactions are considered in CIFS. The subscripts "g", "s" and "aq" denote "gas", "solid" and "aqueous" phase, respectively:

$$
\begin{aligned}
& \left(\mathrm{NH}_{3}\right)_{\mathrm{g}}+\left(\mathrm{HNO}_{3}\right)_{\mathrm{g}} \leftrightarrow\left(\mathrm{NH}_{4} \mathrm{NO}_{3}\right)_{\mathrm{s}} \\
& \left(\mathrm{NH}_{4} \mathrm{NO}_{3}\right)_{\mathrm{s}}+\left(\mathrm{H}_{2} \mathrm{O}\right)_{\mathrm{g}} \leftrightarrow\left(\mathrm{NH}_{4} \mathrm{NO}_{3}\right)_{\mathrm{aq}}+\left(\mathrm{H}_{2} \mathrm{O}\right)_{\mathrm{aq}} \\
& \left(\mathrm{NH}_{4} \mathrm{NO}_{3}\right)_{\mathrm{aq}}+\left(\mathrm{H}_{2} \mathrm{O}\right)_{\mathrm{g}} \leftrightarrow\left(\mathrm{NH}_{4}^{+}\right)_{\mathrm{aq}}+\left(\mathrm{NO}_{3}^{-}\right)_{\mathrm{aq}}+\left(\mathrm{H}_{2} \mathrm{O}\right)_{\mathrm{aq}}
\end{aligned}
$$

\subsection{Model budget diagnostics}

C-IFS computes global diagnostics for every time step to study the contribution of different processes on the global budget. The basic outputs are the total and tropospheric tracer mass, the global integral of the total surface emissions, integrated wet and dry deposition fluxes, chemical conversion, as well as elevated atmospheric emissions and the contributions of prescribed upper and lower vertical boundary conditions for $\mathrm{CH}_{4}$ and $\mathrm{HNO}_{3}$. A time-invariant pressure-based tropopause definition, which varies with latitude, is used to calculate the tropospheric mass. To monitor the numerical integrity of the scheme, the contributions of the corrections to ensure positiveness and global mass conservation are calculated. Optionally, more detailed diagnostics can be requested that includes photolytic loss and the loss by $\mathrm{OH}$ for the tropics and extra-tropics.

A detailed analysis of the global chemistry budget is beyond the scope of this paper. Only a number of key terms for $\mathrm{CO}, \mathrm{O}_{3}$ and $\mathrm{CH}_{4}$ are summarised here. They are compared with values from the Atmospheric Composition Change: the European Network of Excellence (ACCENT) model intercomparisons of chemistry models by Stevenson et al. (2006) for tropospheric $\mathrm{O}_{3}$ and by Shindell et al. (2006) for CO. A more recent inter-comparison was carried out within the Atmospheric Chemistry and Climate Model Intercomparison Project (ACCMIP) (Lamarque et al., 2013). The ACCMIP values have been taken from Young et al. (2013) for tropospheric $\mathrm{O}_{3}$ and from Voulgarakis et al. (2013) for $\mathrm{CH}_{4}$. It should be noted that the values from these inter-comparisons are valid for present-day conditions, but not specifically for 2008. A further source of the differences is the height of the tropopause assumed in the calculations. Overall, the comparison showed that the C-IFS (CB05) is well within the range of the two multi-model ensembles.

The annual mean of the $\mathrm{C}$-IFS tropospheric $\mathrm{O}_{3}$ burden was $390 \mathrm{Tg}$. The values are at the upper end of the range simulated by the ACCENT ( $344 \pm 39 \mathrm{Tg}$ ) and the ACCMIP ( $337 \pm$ $23 \mathrm{Tg}$ ) models. The same holds for the loss by dry deposition, which was $1155 \mathrm{Tg} \mathrm{yr}^{-1}$ for C-IFS, $1003 \pm 200 \mathrm{Tg} \mathrm{yr}^{-1}$ for ACCENT and in the range $687-1350 \mathrm{Tg} \mathrm{yr}^{-1}$ for ACCMIP. The tropospheric chemical $\mathrm{O}_{3}$ production of C-IFS was $4608 \mathrm{Tg} \mathrm{yr}^{-1}$ and loss $4144 \mathrm{Tg} \mathrm{yr}^{-1}$, which is for both values at the lower end of the range reported for the production $\left(5110 \pm 606 \mathrm{Tg} \mathrm{yr}^{-1}\right)$ and loss $\left(4668 \pm 727 \mathrm{Tg} \mathrm{yr}^{-1}\right)$ for the ACCENT models. The comparatively simple treatment of volatile organic compounds in CB05 could be an explanation for the low $\mathrm{O}_{3}$ production and loss terms. Stratospheric inflow in C-IFS, estimated as the residue from the remaining terms was $691 \mathrm{Tg}$ and the corresponding value from the ACCENT multi-model mean is $552 \pm 168 \mathrm{Tg}$.

The annual mean total CO burden in C-IFS was $361 \mathrm{Tg}$, which is slightly larger than the ACCENT mean (345, 248$427 \mathrm{Tg}$ ). The total $\mathrm{CO}$ emissions in 2008 were $1008 \mathrm{Tg}$, which is in line with the number used in ACCENT 
$\left(1077 \mathrm{Tg} \mathrm{yr}^{-1}\right)$ but lower than the estimate $\left(1550 \mathrm{Tg} \mathrm{yr}^{-1}\right)$ of the Third Assessment Report (Prather and Ehhalt, 2001) of the Intergovernmental Panel on Climate Change (IPCC), which also takes into account results from inverse modelling studies. The tropospheric chemical CO production was $1434 \mathrm{Tg} \mathrm{yr}^{-1}$, which is very close to the ACCENT multimean of $1505 \pm 236 \mathrm{Tg} \mathrm{yr}^{-1}$. The chemical CO loss in C-IFS was $2423 \mathrm{Tg}$ and the loss by dry deposition $24 \mathrm{Tg}$.

The annual mean $\mathrm{CH}_{4}$ total and tropospheric burdens of C-IFS (CB05) are 4874 and $4271 \mathrm{Tg} \mathrm{yr}^{-1}$, respectively. The global chemical $\mathrm{CH}_{4}$ loss by $\mathrm{OH}$ was $467 \mathrm{Tg} \mathrm{yr}^{-1}$. Following Stevenson et al. (2006), this leads to a global $\mathrm{CH}_{4}$ lifetime estimate of 9.1 years. This value is within the ACCMIP range of $9.8 \pm 1.6$ years but lower than an observation-based $11.2 \pm 1.3$ years estimate by Prather et al. (2012). $\mathrm{CH}_{4}$ emissions were substituted by prescribed monthly zonal-mean surface concentrations to avoid the long-spin up needed by a direct modelling of the $\mathrm{CH}_{4}$ surface fluxes. The $\mathrm{CH}_{4}$ surface concentrations were derived from a latitudinal interpolation of observations from the South Pole, Cape Grim, Mauna Loa, Mace Head, Barrow and Alert stations as discussed in Bândă et al. (2015). The resulting $\mathrm{CH}_{4}$ flux was $488 \mathrm{Tg} \mathrm{yr}^{-1}$, which is of similar size as the sum of current estimates of the total $\mathrm{CH}_{4}$ emissions of $500-580 \mathrm{Tg} \mathrm{yr}^{-1}$ and the loss by soils of $30-40 \mathrm{Tg} \mathrm{yr}^{-1}$ (Forth Assessment Report by IPCC http://www.ipcc.ch/publications_and_data/ar4/ wg1/en/ch7s7-4-1.html\#ar4top).

\section{Evaluation with observations and comparison with the IFS-MOZART coupled system}

The main motivation for the development of C-IFS is forecasting and assimilation of atmospheric composition as part of the CAMS. Hence, the purpose of this evaluation is to show how C-IFS (CB05) performs relative to the MOZART3 coupled CTM (Kinnison et al., 2007), which has been running in the IFS-MOZART coupled system in pre-operational mode since 2007. C-IFS will replace the coupled system in the next update of the CAMS system. The evaluation focuses on species which are relevant to global air pollution such as tropospheric $\mathrm{O}_{3}, \mathrm{CO}$, nitrogen dioxide $\left(\mathrm{NO}_{2}\right), \mathrm{SO}_{2}$ and formaldehyde (HCHO). The MACC re-analysis (Inness et al., 2013), which is an application of IFS-MOZART with assimilation of observations of atmospheric composition, has been included in the evaluation as a benchmark.

The MACC re-analysis (REAN) and the corresponding MOZART (MOZ) stand-alone run have already been evaluated with observations by Inness et al. (2013). Furthermore, the MACC-II sub-project on validation has compiled a comprehensive report assessing REAN (MACC, 2013). REAN has been further evaluated with surface observations in Europe and North America for $\mathrm{O}_{3}$ by Im et al. (2014). C-IFS (CB05) has been already evaluated with a special focus on hydroperoxyl $\left(\mathrm{HO}_{2}\right)$ in relation to $\mathrm{CO}$ in Huij- nen et al. (2014). The performance of an earlier version of C-IFS (CB05) in the Arctic was evaluated and intercompared with CTMs of the POLARCAT model intercomparison Project (POLMIP) by Monks et al. (2014) for CO and Arnold et al. (2014) for reactive nitrogen. The POLMIP inter-comparisons show that C-IFS (CB05) performs within the range of state-of-the-art CTMs.

\subsection{Summary of model runs set-up}

C-IFS (CB05) was run from 1 January to 31 December 2008 with a spin-up starting 1 July 2007 at a T255 resolution $(80 \mathrm{~km} \times 80 \mathrm{~km})$ with 60 model levels in monthly chunks. The meteorological simulation was relaxed to dynamical fields of the MACC re-analysis (see Sect. 2.1). Likewise, stratospheric $\mathrm{O}_{3}$ above the tropopause was nudged to the MACC re-analysis.

MOZ is a run with the MOZART CTM at $1.1^{\circ} \times 1.1^{\circ}$ $(120 \times 120 \mathrm{~km})$ horizontal resolution using the 60 vertical levels of C-IFS. The set-up of the MOZART model and the applied emissions and dry deposition velocities were the same in MOZ and REAN. The most important difference between MOZ and REAN is the assimilation of satellite retrieval of atmospheric composition in REAN. Furthermore, REAN was produced with the IFS-MOZART coupled system, whereas MOZ is a stand-alone system driven by the meteorological fields of REAN. The latter is equivalent to a simulation of IFS-MOZART without data assimilation of atmospheric composition. The assimilated retrievals were $\mathrm{CO}$ and $\mathrm{O}_{3}$ total columns, stratospheric $\mathrm{O}_{3}$ profiles and tropospheric $\mathrm{NO}_{2}$ columns. No observations of atmospheric composition have been feed in to the MOZ run. No observational information has been used to improve the tropospheric simulation of the C-IFS run. Another difference between MOZ and REAN is that the IFS diffusion and convection scheme, as used in C-IFS, controls the vertical transport in REAN, whereas MOZART's generic schemes were used in the MOZ run.

MOZ, REAN and C-IFS used the same anthropogenic emissions (MACCity), biogenic emissions (MEGAN 2.1; Guenther et al., 2006, http: //acd.ucar.edu/ guenther/MEGAN/MEGAN.htm) and natural emissions from the POET project. The biomass burning emissions for MOZ and REAN came from the Global Fire Emission Data version 3 inventory which was redistributed according to fire radiative power observations used in GFAS. Hence, the average biomass burning emissions used by MOZART (MOZ and REAN) agree well with the GFAS emissions used by C-IFS, but they are not identical in temporal and spatial variability.

\subsection{Observations}

The runs (C-IFS, MOZ, REAN) were evaluated with $\mathrm{O}_{3}$ observations from ozonesondes and $\mathrm{O}_{3}$ and $\mathrm{CO}$ aircraft pro- 
Table 2. Ozonesonde sites used in the evaluation for different regions.

\begin{tabular}{|c|c|c|}
\hline Region & Area S/W/N/E & Stations (number of observations) \\
\hline Europe & $35^{\circ} \mathrm{N} / 20^{\circ} \mathrm{W} / 60^{\circ} \mathrm{N} / 40^{\circ} \mathrm{E}$ & $\begin{array}{l}\text { Barajas (52), DeBilt (57), Hohenpeissenberg (126), Legionowo (48), Lindenberg } \\
\text { (52), Observatoire de Haute-Provence (46), Payerne (158), Prague (49), Uccle (142) } \\
\text { and Valentia Observatory (49) }\end{array}$ \\
\hline North America & $30^{\circ} \mathrm{N} / 135^{\circ} \mathrm{W} / 60^{\circ} \mathrm{N} / 60^{\circ} \mathrm{W}$ & $\begin{array}{l}\text { Boulder (65), Bratts Lake (61), Churchill (61), Egbert (29), Goose Bay (47), } \\
\text { Kelowna (72), Stony Plain (77), Wallops (51), Yarmouth (60), Narragansett (7) and } \\
\text { Trinidad Head (35) }\end{array}$ \\
\hline Arctic & $60^{\circ} \mathrm{N} / 180^{\circ} \mathrm{W} / 90^{\circ} \mathrm{N} / 180^{\circ} \mathrm{E}$ & $\begin{array}{l}\text { Alert (52), Eureka (83), Keflavik (8), Lerwick (49), Ny-Aalesund (77), Resolute } \\
\text { (63), Scoresbysund (54), Sodankyla (63), Summit (81) and Thule (15) }\end{array}$ \\
\hline Tropics & $20^{\circ} \mathrm{S} / 180^{\circ} \mathrm{W} / 20^{\circ} \mathrm{N} / 180^{\circ} \mathrm{E}$ & $\begin{array}{l}\text { Alajuela (47), Ascension Island (32), Hilo (47), Kuala Lumpur (24), Nairobi (39), } \\
\text { Natal (48), Paramaribo (35), Poona (13), Samoa (33), San Cristobal (28), Suva (28), } \\
\text { Thiruvananthapuram (12) and Watukosek (19) }\end{array}$ \\
\hline East Asia & $15^{\circ} \mathrm{N} / 100^{\circ} \mathrm{E} / 45^{\circ} \mathrm{N} / 142^{\circ} \mathrm{E}$ & Hong Kong Observatory (49), Naha (37), Sapporo (42) and Tateno Tsukuba (49) \\
\hline Antarctic & $90^{\circ} \mathrm{S} / 180^{\circ} \mathrm{W} / 60^{\circ} \mathrm{S} / 180^{\circ} \mathrm{E}$ & $\begin{array}{l}\text { Davis (24), Dumont d'Urville (38), Maitri (9), Marambio (66), Neumayer (72), } \\
\text { South Pole (63), Syowa (41) and McMurdo (18) }\end{array}$ \\
\hline
\end{tabular}

files from the Measurement of Ozone, Water Vapour, Carbon Monoxide and Nitrogen Oxides by Airbus in-service Aircraft (MOZAIC) program. Simulated surface $\mathrm{O}_{3}, \mathrm{CO}$, $\mathrm{NO}_{2}$ and $\mathrm{SO}_{2}$ fields were compared against Global Atmospheric Watch (GAW) surface observations and additionally $\mathrm{O}_{3}$ against observations from the European Monitoring and Evaluation Programme (EMEP) and the European air quality database (AirBase). The global distributions of tropospheric $\mathrm{NO}_{2}$ and $\mathrm{HCHO}$ were evaluated with retrievals of tropospheric columns from Global Ozone Monitoring Experiment 2 (GOME-2). Measurements Of Pollution In The Troposphere (MOPITT) retrievals were used for the validation of the global CO total column fields.

\subsubsection{In situ observations}

The ozonesondes were obtained from the World Ozone and Ultraviolet Radiation Data Centre (WOUDC) and from the ECWMF Meteorological Archive and Retrieval System. The observation error of the sondes is about $\pm 5 \%$ in the range from 200 to $10 \mathrm{hPa}$ and $-7-17 \%$ below $200 \mathrm{hPa}$ (Beekmann et al., 1994; Komhyr et al., 1995, and Steinbrecht et al., 1998). The number of soundings varied for the different stations. Typically, the sondes are launched once a week but in certain periods such as during $\mathrm{O}_{3}$ hole conditions soundings are more frequent. Sonde launches were carried out mostly between 9 and $12 \mathrm{~h}$ local time. The global distribution of the launch sites is even enough to allow meaningful averages over larger areas such North America, Europe, the tropics, the Artic and Antarctica. Table 2 contains a list of the ozonesondes used in this study. Tilmes et al. (2012) suggest a further refinement of the North America region into Canada and the eastern and western United States as well of the tropics into Atlantic Africa, the equatorial Americas and the eastern Indian Ocean / western Pacific based on the intercomparison of ozonesonde observations for the 1994-2010 period. The results will also be discussed for the sub-regions and figures will be presented in the Supplement.

The MOZAIC program (Marenco et al., 1998, and Nédélec et al., 2003) provides profiles of various trace gases taken during commercial aircraft ascents and descents at specific airports. MOZAIC CO data have an accuracy of \pm 5 ppbv, a precision of $\pm 5 \%$, and a detection limit of 10 ppbv (Nédélec et al., 2003). Since the aircraft carrying the MOZAIC unit were based in Frankfurt, the majority of the CO profiles (837 in 2008) were observed at this airport. A further 10 of the 28 airports with observations in 2008 had a sufficient number of profiles: Windhoek (323), Caracas (129), Hyderabad (125) and London-Gatwick (83) as well as North American airports Atlanta (104), Portland (69), Philadelphia (65), Vancouver (56), Toronto (46) and Dallas (43). The North American airports were considered to be close enough to make a spatial average meaningful. Because of the varying data availability the North American mean is dominated by the airports in the eastern United States.

Apart from Frankfurt, typically two profiles (takeoff and landing) are taken within $2-3 \mathrm{~h}$ or with a longer gap in the case of an overnight stay. At Frankfurt there were two to six profiles available each day, mostly in the morning and the later afternoon to the evening. At the other airports the typical observation times were 06:00 and 18:00 UTC for Windhoek ( $\pm 0 \mathrm{~h}$ local time), 19:00 and 21:00 UTC for Hyderabad $(+4 \mathrm{~h}$ local time), 20:00 and 22:00 UTC for Caracas (-6h), 04:00 and 22:00 for London $( \pm 0 \mathrm{~h})$ and 19:00 and 22:00 $(-5 / 6 \mathrm{~h})$ for the North American airports. This means that most of the observations were taken between the late evening and early morning hours, i.e. at a time of increased stability and large 
$\mathrm{CO}$ vertical gradients close to the surface. Only the observations at Caracas (afternoon) and to some extent in Frankfurt represent a more mixed day-time boundary layer. The modelled column profile was obtained at the middle between the start and end times of the profile observation and no consideration was given to the horizontal movement of the aircraft. The model columns were interpolated in time between two subsequent output time steps.

The global atmospheric watch (GAW) program of the World Meteorological Organization is a network for mainly surface based observations (WMO, 2007). The data were retrieved from the World Data Centre for Greenhouse Gases (http://ds.data.jma.go.jp/gmd/wdcgg/). The GAW observations represent the global background away from the main polluted areas. Often, the GAW observation sites are located on mountains, which makes it necessary to select a model level different from the lowest model level for a sound comparison with the model. In this study the procedure described in Flemming et al. (2009b) is applied to determine the model level, which is based on the difference between a high-resolution orography and the actual station height. The data coverage for $\mathrm{CO}$ and $\mathrm{O}_{3}$ was global, whereas for $\mathrm{SO}_{2}$ and $\mathrm{NO}_{2}$, only a few observations in Europe were available at the data repository.

The Airbase and EMEP databases host operational air quality observations from different national European networks. All EMEP stations are located in rural areas, while Airbase stations are designed to monitor local pollution. Many AirBase observations may therefore not be representative of a global model with a horizontal resolution of $80 \mathrm{~km}$. However, stations of rural regime may capture the largerscale signal, in particular for $\mathrm{O}_{3}$, which is spatially well correlated (Flemming et al., 2005). The EMEP observations and the rural Airbase $\mathrm{O}_{3}$ observations were used for the evaluation over Europe.

\subsubsection{Satellite retrievals}

Satellite retrievals of atmospheric composition are more widely used to evaluate model results. Satellite data provide good horizontal coverage but have limitation with respect to the vertical resolution and signal from the lowest atmospheric levels. Furthermore, satellite observations are only possible at the specific overpass time, and they can be disturbed by the presence of clouds and surface properties. Depending on the instrument type global coverage is achieved in several days.

Day-time CO total column retrievals from MOPITT, version 6 (Deeter, 2013), and retrievals of tropospheric columns of $\mathrm{NO}_{2}$ (IUP-UB v0.7, Richter et al., 2005) and of HCHO (IUP-UB v1.0; Wittrock et al., 2006) from GOME-2 (Callies et al., 2000) have been used for the evaluation. The retrievals were averaged to monthly means values to reduce the random retrieval error.
MOPITT is a multispectral thermal infrared (TIR)/near infrared (NIR) instrument onboard the TERRA satellite with a pixel resolution of $22 \mathrm{~km}$. TERRA's local equatorial crossing time is approximately 10:30 a.m. The MOPITT CO level 2 pixels were binned within $1 \times 1^{\circ}$ within each month. Deeter et al. (2013) report a bias of about $+0.08 \times 10^{18}$ molec $\mathrm{cm}^{-2}$ and a standard deviation (SD) of the error of $0.19 \times 10^{18}$ molec cm $^{-2}$ for the TIR/NIR product version 5. This is equivalent to a bias of about $4 \%$ and a SD of $10 \%$ respectively assuming typical observations of $2.0 \times 10^{18} \mathrm{molec} \mathrm{cm}^{-2}$. For the calculation of the simulated $\mathrm{CO}$ total column, the a priori profile in combination with the averaging kernels (AK) of the retrievals was applied. They have the largest values between 300 and $800 \mathrm{hPa}$. The AK have been applied to ensure that the difference between retrieval and the AK-weighted model column is independent of the a priori $\mathrm{CO}$ profiles used in the retrieval. One should note however, that the AK-weighted column is not equivalent to the modelled atmospheric $\mathrm{CO}$ burden anymore.

GOME-2 is a ultra violet-visible (UV-VIS) and NIR sensor designed to provide global observations of atmospheric trace gases. GOME-2 flies in a sun-synchronous orbit with an equatorial crossing time of 09:30 LT in descending mode and has a footprint of $40 \times 80 \mathrm{~km}$. Here, tropospheric vertical columns of $\mathrm{NO}_{2}$ and $\mathrm{HCHO}$ have been computed using a three step approach. First, the differential optical absorption spectroscopy (DOAS; Platt, 1994) method is applied to measured spectra which yields the total slant column. The DOAS method is applied in a $425-497 \mathrm{~nm}$ wavelength window (Richter et al., 2011) for $\mathrm{NO}_{2}$. and between 337 and $353 \mathrm{~nm}$ for HCHO (Vrekoussis et al., 2010). Second, the reference sector approach is applied to total slant columns for stratospheric correction. In a last step, tropospheric slant columns are converted to tropospheric vertical columns by applying an air mass factor. Only data with cloud fractions smaller than 0.2 according to the FRESCO cloud database (Wang et al., 2008) are used here. Furthermore, retrievals are limited to maximum solar zenith angles of $85^{\circ}$ for $\mathrm{NO}_{2}$ and $60^{\circ}$ for $\mathrm{HCHO}$. Uncertainties in $\mathrm{NO}_{2}$ satellite retrievals are large and depend on the region and season. Winter values at middle and high latitudes are usually associated with larger error margins. As a rough estimate, systematic uncertainties in regions with significant pollution are of the order of 20$30 \%$. As the HCHO retrieval is performed in the UV part of the spectrum where less light is available and the $\mathrm{HCHO}$ absorption signal is smaller than that of $\mathrm{NO}_{2}$, the uncertainty of monthly mean $\mathrm{HCHO}$ columns is relatively large (20-40\%) and both noise and systematic offsets have an influence on the results. However, absolute values and seasonality are retrieved more accurately over $\mathrm{HCHO}$ hotspots.

For comparison to GOME-2 data, model data are vertically integrated without applying $\mathrm{AK}$ to tropospheric vertical columns of $\mathrm{NO}_{2}$ and $\mathrm{HCHO}$, interpolated to satellite observation time and then sampled to match the location of available cloud free satellite data, which has been gridded to 

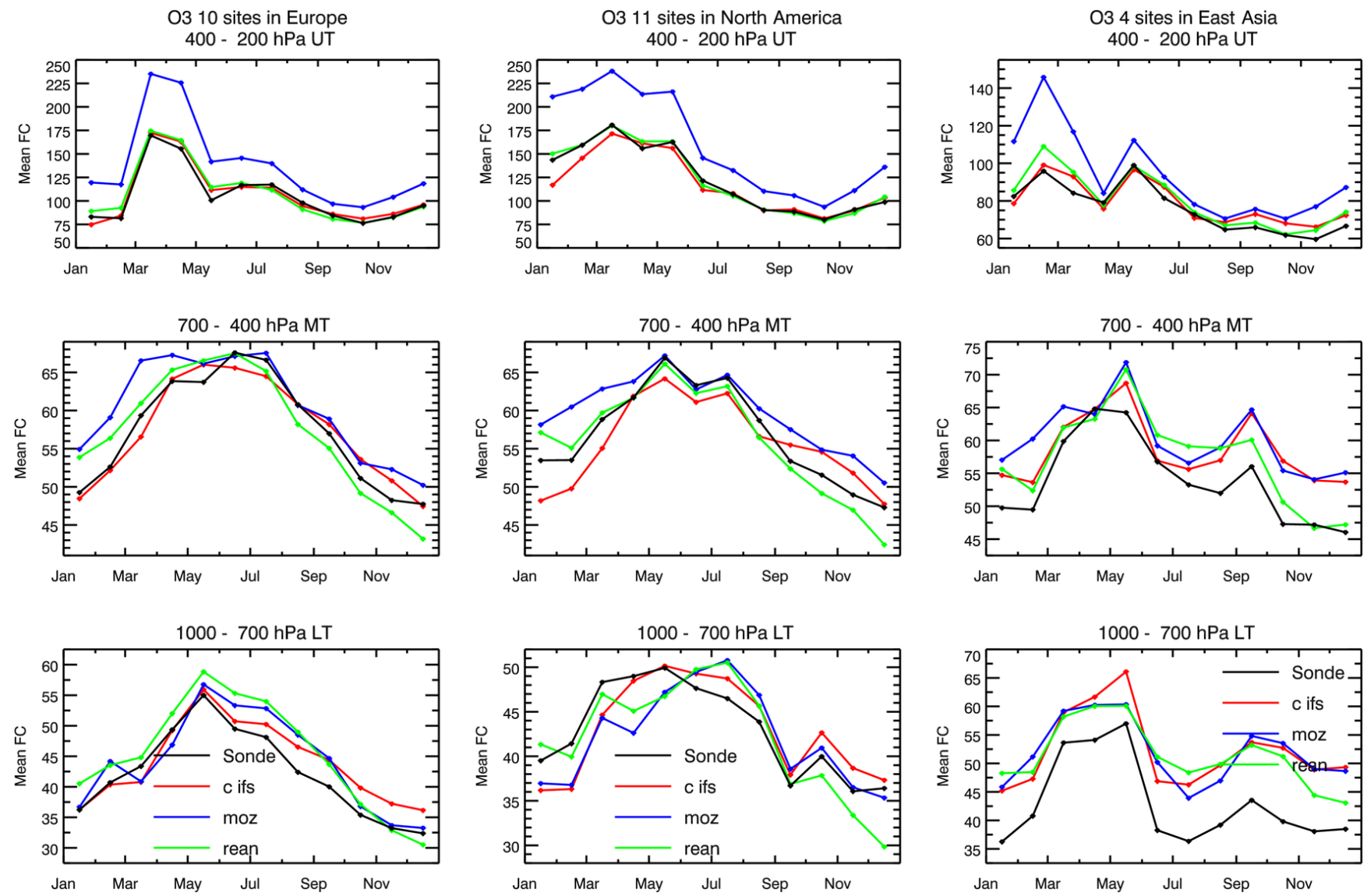

Figure 2. Tropospheric ozone volume mixing ratios (ppb) over Europe (left) and North America (middle) and East Asia (right) averaged in the pressure ranges $1000-700 \mathrm{hPa}$ (bottom), $700-400 \mathrm{hPa}$ (middle) and 400-200 hPa (top) observed by ozonesondes (black) and simulated by C-IFS (red), MOZ (blue) and REAN (green) in 2008.

match the model resolution. The resulting daily files are then averaged over months for both satellite and model data to reduce the noise.

\subsection{Tropospheric ozone}

Figure 2 shows the monthly means of $\mathrm{O}_{3}$ volume mixing ratios in the pressure ranges surface to $700 \mathrm{hPa}$ (lower troposphere, LT) 700-400 hPa (middle troposphere, MT) and 400-200 hPa (upper troposphere UT) observed by sondes and averaged over Europe, North America and East Asia. Figure 3 shows the same as Fig. 2 for the tropics, Arctic and Antarctica. A more detailed breakdown of North America (Canada, eastern and western United States) and the tropics (Atlantic Africa, equatorial Americas and eastern Indian Ocean/western Pacific) following Tilmes et al. (2012) is presented in the supplement. The observations have a pronounced spring maximum for UT $\mathrm{O}_{3}$ over Europe, North America and East Asia and a more gradually developing maximum in late spring and summer in MT and LT. The LT seasonal cycle is well re-produced in all runs for the areas of the Northern Hemisphere (NH). In Europe, REAN tends to overestimate by about $5 \mathrm{ppb}$ where the C-IFS and MOZ have almost no bias before the annual maximum in May apart from a small negative bias in spring. Later in the year, C-IFS tends to overestimate in autumn, whereas MOZ overestimates more in late summer. In MT over Europe, CIFS agrees slightly better with the observations than MOZ. $\mathrm{MOZ}$ overestimates in winter and spring and this overestimation is more prominent in the UT, where MOZ is biased high throughout the year. This overestimation in UT is highest in spring, where it can be $25 \%$ and more. These findings show that data assimilation in REAN improved UT $\mathrm{O}_{3}$ considerably but had only little influence in LT and MT. The overestimation of MOZ in UT seems to be caused by increased stratospheric $\mathrm{O}_{3}$ rather than a more efficient transport as lower stratospheric $\mathrm{O}_{3}$ was overestimated in MOZ. Note that stratospheric ozone in C-IFS was nudged to the MACC re-analysis (see Sect. 3.1) but good agreement of C-IFS with observation in UT in all three regions is also present in a run without nudging to stratospheric $\mathrm{O}_{3}$. It is therefore not only a consequence of the use of assimilated observations in C-IFS (CB05). 

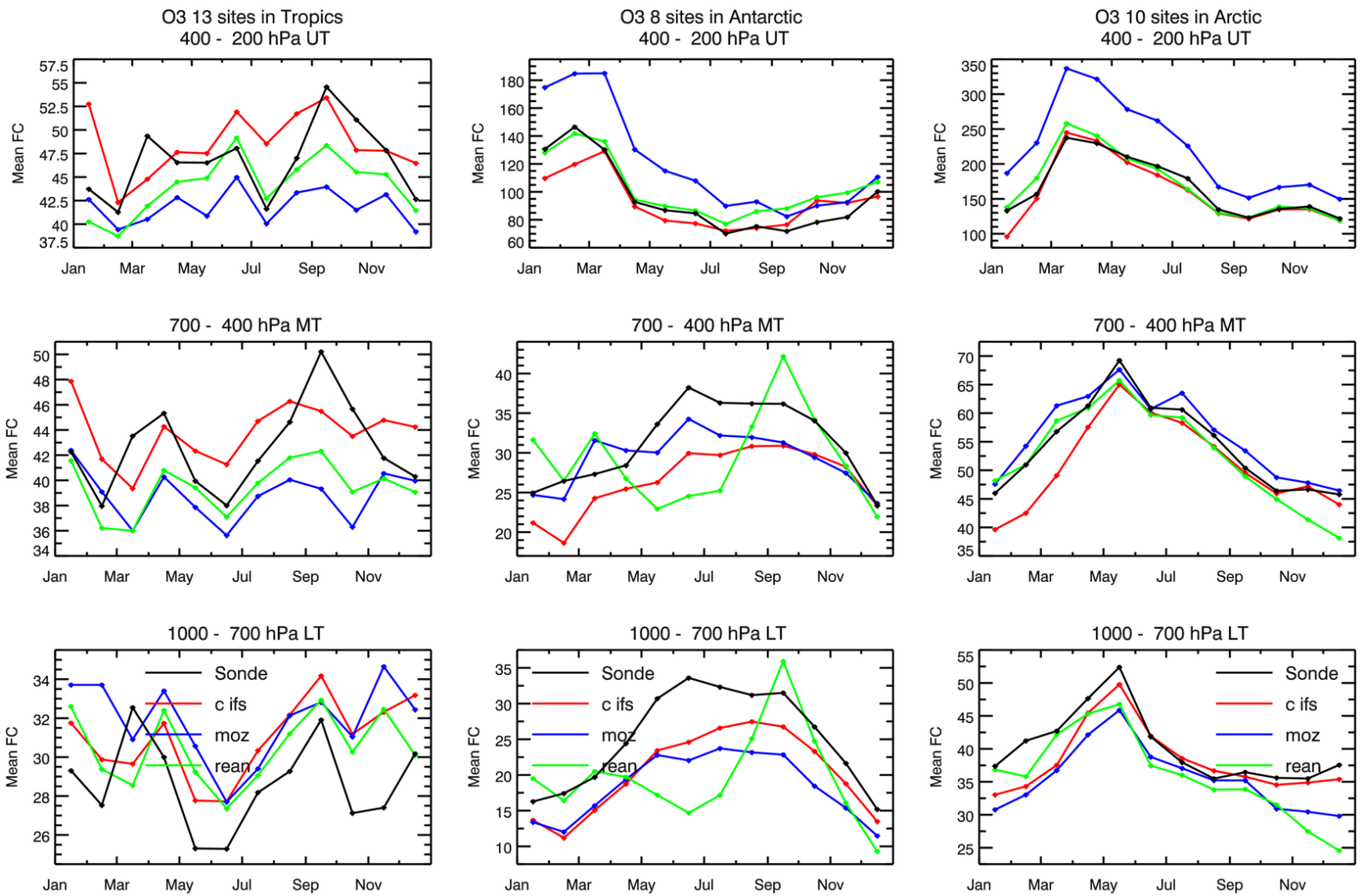

Figure 3. Tropospheric ozone volume mixing ratios (ppb) over the tropics (left), Antarctica (middle) and the Arctic (right) averaged in the pressure bands 1000-700 hPa (bottom), 700-400 hPa (middle) and 400-200 hPa (top) observed by ozonesondes and simulated by C-IFS (red), MOZ (blue) and REAN (green) in 2008.

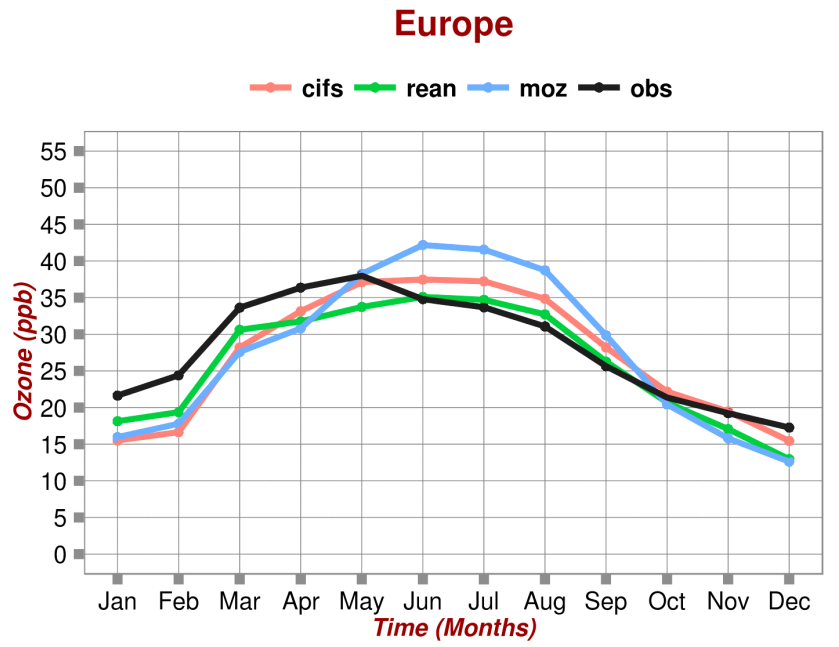

Figure 4. Annual cycle of the mean ozone volume mixing ratios $(\mathrm{ppb})$ at rural sites of the EMEP and AirBase database and simulated by C-IFS (red), MOZ (blue) and REAN (green).
Over North America the spring-time underestimation by $\mathrm{C}$-IFS and MOZ is more pronounced than over Europe. The underestimation occurs in all regions but was largest in early spring over Canada. C-IFS also underestimates spring ozone throughout North America in MT. LT summer-time ozone was overestimated in North America by all models, in particular over the eastern United States. The bias of C-IFS was the smallest in LT but, in contrast to MOZ and REAN, C-IFS underestimates summer-time ozone in MT over the eastern United States. The overestimation of UT ozone by MOZ was most pronounced in Canada.

In East Asia all runs overestimate by $5-10 \mathrm{ppb}$ in LT and MT, especially in autumn and winter. At the northern high latitudes (Fig. 3) the negative spring bias appears in all runs in LT and only for C-IFS in MT. As in the other regions, $\mathrm{MOZ}$ greatly overestimates $\mathrm{UT} \mathrm{O}_{3}$.

Averaged over the tropics, the annual variability is below $10 \mathrm{ppb}$, with maxima in May and in September caused by the dry season in South America (May) and Africa (September). The variability is well reproduced and biases are mostly below $5 \mathrm{ppb}$ in the whole troposphere. Note that the 400 


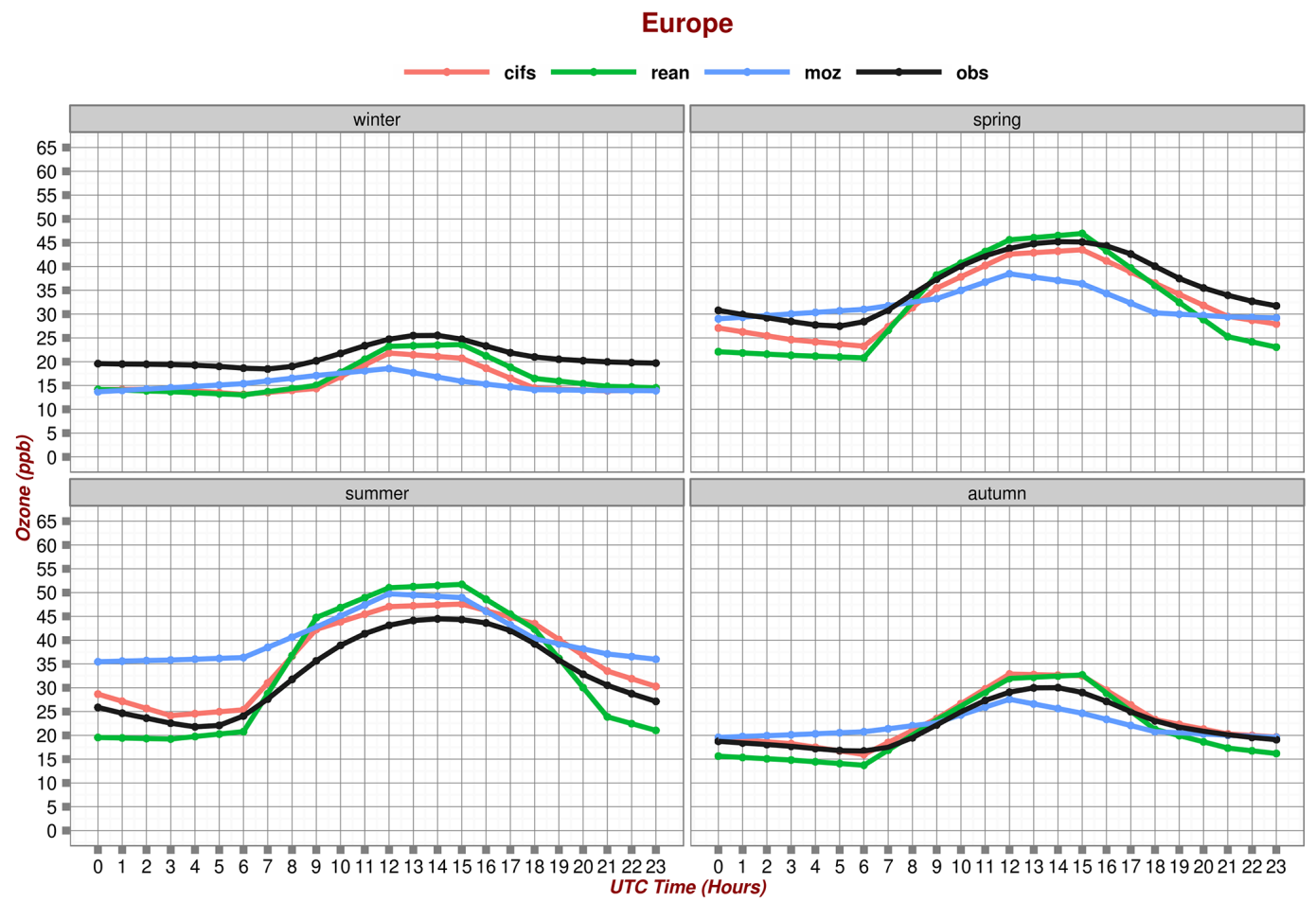

Figure 5. Diurnal cycle of surface ozone volume mixing ratios (ppb) over Europe in winter (top, left), spring (top, right), summer (bottom, left) and autumn (bottom, right) at the rural site of the EMEP and AirBase database and simulated by C-IFS (red), MOZ (blue) and REAN (green).

$200 \mathrm{hPa}$ range (UT) in the tropics is less influenced by the stratosphere because of the higher tropopause. C-IFS had smaller biases because of lower values in LT and higher values in MT and UT than MOZ. A more detailed analysis for different tropical regions shows that the seasonality is well captured by all models over Atlantic Africa, equatorial America and the eastern Indian Ocean / western Pacific in all three tropospheric levels. However, the strong observed monthly anomalies (an observation glitch by one station) in equatorial America in March and September were underestimated by up to $20 \mathrm{ppb}$ in all tropospheric levels.

Over the Arctic, C-IFS and MOZ reproduce the seasonal cycle, which peaks in late spring, but generally underestimate the observations in LT. C-IFS had a smaller bias in LT than MOZ but had a larger negative bias in MT. The biggest improvement in C-IFS w.r.t. to MOZ occurred at the surface in Antarctica as the biases compared to the GAW surface observations were greatly reduced. Notably, the assimilation (REAN) led to increased biases for LT and MT $\mathrm{O}_{3}$, in particular during polar night when UV satellite observations are not available, as already discussed in Flemming et al. (2011).

The ability of the models to simulate $\mathrm{O}_{3}$ near the surface is tested with rural AirBase and EMEP stations (see Sect. 3.2). Figure 4 shows monthly means and Fig. 5 the average diurnal cycle in different seasons in Europe. All runs underestimate monthly mean $\mathrm{O}_{3}$ in spring and winter and overestimate it in late summer and autumn. The overestimation in summer was largest in MOZ. The recently reported (Val Martin at al., 2014) missing coupling of the leaf area index to the leaf and stomatal vegetation resistance in the calculation of dry deposition velocities could be an explanation of the MOZ bias. While the overestimation appeared also with respect to the ozonesondes in LT (see Fig. 2, left), the spring-time underestimation was less pronounced in LT.

The comparison of the diurnal cycle with observations (Fig. 5) shows that C-IFS produced a more realistic diurnal cycle than the MOZART model. The diurnal variability simulated by the MOZART model is much less pronounced than the observations suggest. The diurnal cycles of C-IFS and REAN were similar. This finding can be explained by the fact that C-IFS and REAN use the IFS diffusion scheme, whereas MOZART applies the diffusion scheme of the MOZART CTM.

The negative bias of C-IFS in winter and spring seems mainly caused by an underestimation of the night-time values, whereas the overestimations of the summer and autumn average values in C-IFS were caused by an overestimation of the day-time values. However, the overestimation of the summer night-time values by MOZART seems to be a strong contribution to the average overestimation in this season. 

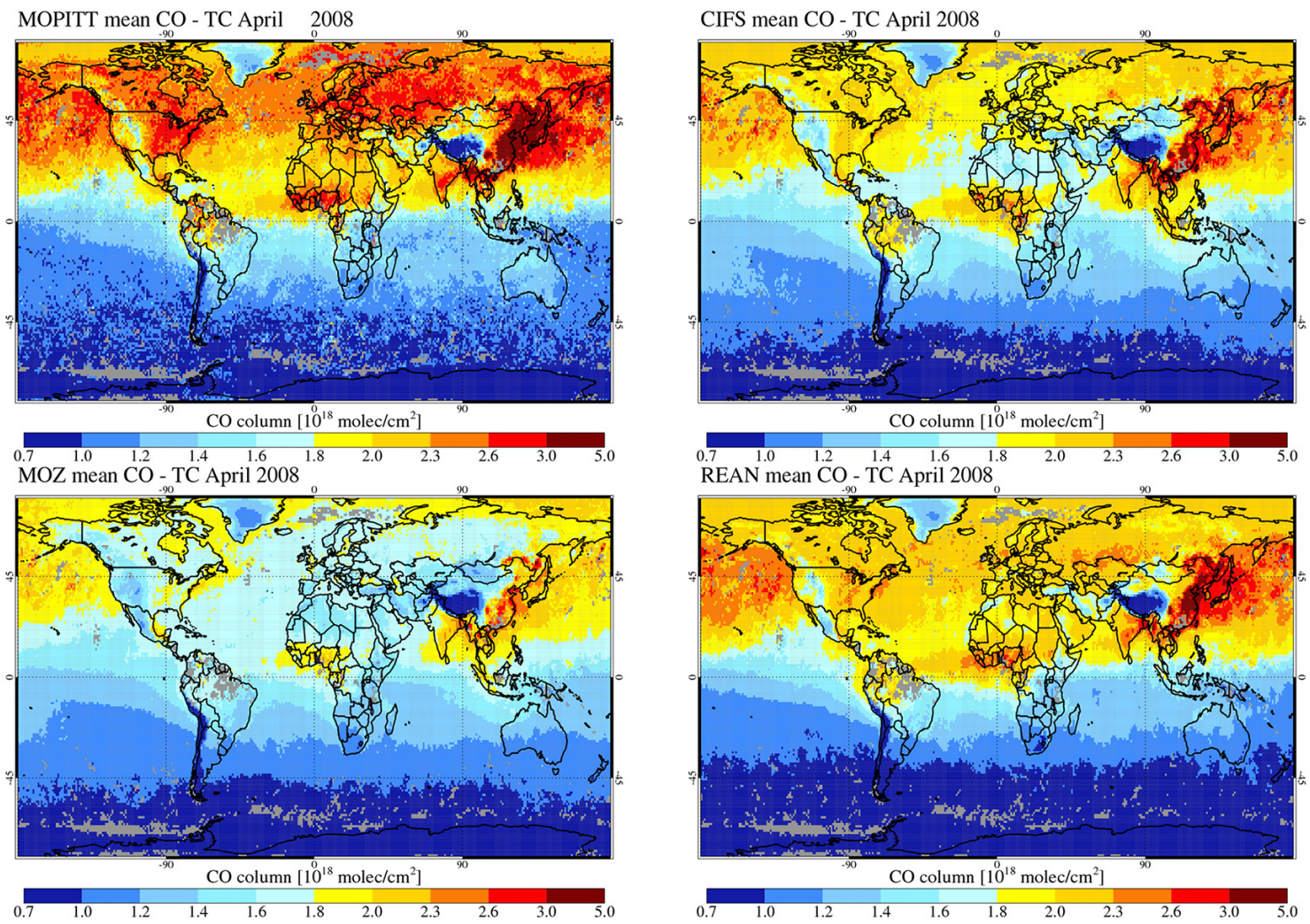

Figure 6. CO total column retrieval (MOPITT V6) for April 2008 (top left) and simulated by C-IFS (top right), MOZ (bottom left) and REAN (bottom right); AK are applied.

\subsection{Carbon monoxide}

The seasonality of $\mathrm{CO}$ is mainly driven by its chemical lifetime, which is lower in summer because of increased photochemical activity. The seasonal cycle of the $\mathrm{CO}$ emissions also plays an important role in the case of biomass burning and high anthropogenic emissions. The global distribution of total column CO retrieved from MOPITT and from AK-weighted columns simulated by C-IFS, MOZ and REAN is shown for April 2008 in Fig. 6 and for August in Fig. 7. Figures showing the corresponding biases can be found in the Supplement. April and August have been selected because they are the months of the NH CO maximum and minimum. C-IFS reproduced well the locations of the observed global maxima in North America, Europe and China, as well as the biomass burning signal in central Africa. However, there was a widespread underestimation of the MOPITT values in the $\mathrm{NH}$, which was strongest over European Russia and northern China. Tropical CO was slightly overestimated, but more strongly over Southeast Asia in April at the end of the biomass burning season in this region. The lower $\mathrm{CO}$ columns at middle and high latitudes in the Southern Hemisphere $(\mathrm{SH})$ were underestimated. The same global gradients of the bias were found in MOZ and REAN. The negative $\mathrm{NH}$ bias in April of MOZ is however more pronounced, but the positive bias in the tropics is slightly reduced. The bias of MOZ seems stronger over the entire land surface in the $\mathrm{NH}$ and not predominantly in the areas with high emission. This is consistent with the finding of Stein et al. (2014) that dry deposition, besides underestimated emissions, contributes to the large negative biases in the $\mathrm{NH}$ in MOZ. Assimilating MOPITT (V4) into REAN led to much reduced biases everywhere even though the sign of bias in the $\mathrm{NH}$, tropics and $\mathrm{SH}$ remained. In August, the NH bias is reduced, but the hemispheric pattern of the CO bias was similar to April for all runs. The only regional exception from the general overestimation in the tropics is the strong underestimation of $\mathrm{CO}$ in the biomass burning maximum in southern Africa, which points to an underestimation of the GFAS biomass burning emissions in that area.

More insight into the seasonal cycle and the vertical $\mathrm{CO}$ distribution can be obtained from MOZAIC aircraft profiles. CO profiles at Frankfurt (Fig. 8, left) provide a continuous record with about two to six observations per day. As already reported in Inness et al. (2013) and Stein et al. (2014), MOZ underestimates strongly LT CO with a negative bias of $40-60 \mathrm{ppb}$ throughout the whole year. The highest underestimation occurred in April and May, i.e. at the time of the observed CO maximum. C-IFS CB05 also underestimates $\mathrm{CO}$ but with a smaller negative bias in the range of 20 

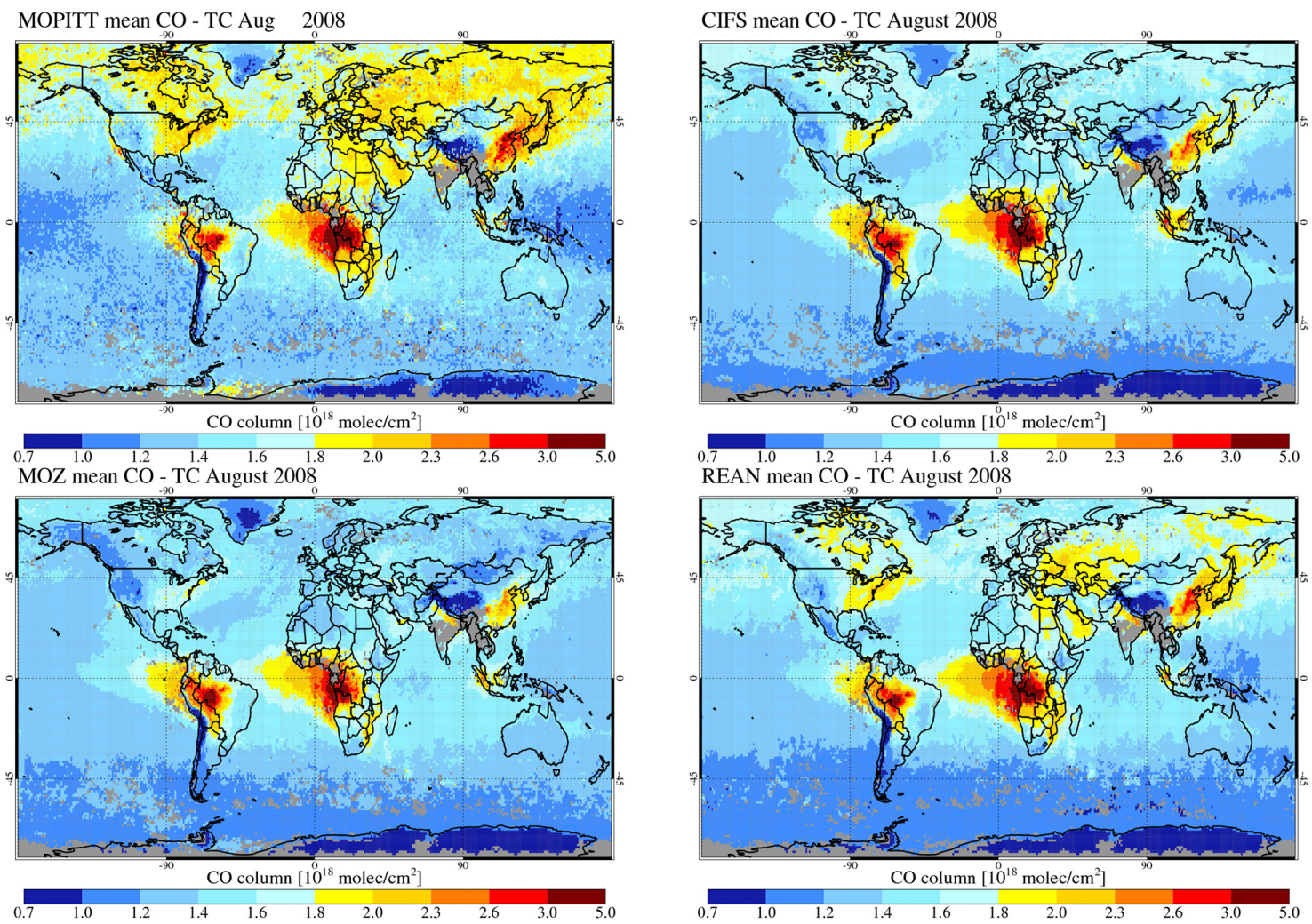

Figure 7. CO total column retrieval (MOPITT V6) for August 2008 (top left) and simulated by C-IFS (top right), MOZ (bottom left) and REAN (bottom right); AK are applied.

$40 \mathrm{ppb}$ even though it used the same $\mathrm{CO}$ emission data as MOZ. REAN has the lowest bias throughout the year, but the improvement is more important in winter and early spring. The comparison over London, which is representative for 04:00 and 22:00 UTC, leads to similar results as for Frankfurt (Fig. 8, middle). The seasonal variability of LT CO from MOZAIC and the model runs in North America are very similar to the one in Europe (Fig. 8, right). The late winter and spring bias is slightly increased, whereas the summer-time bias was lower for all models. The surface bias in winter and spring of MOZ, C-IFS and REAN is about $-50,-40$ and $-20 \mathrm{ppb}$, respectively. In the rest of the year REAN and CIFS have a bias of about $-15 \mathrm{ppb}$, whereas the bias of MOZ is about twice as large.

MT CO was very well produced by REAN in Europe and North America, probably because MOPITT has the highest sensitivity at this level. The MT bias of C-IFS is about $75 \%$ of the bias of MOZ, which underestimates by about $30 \mathrm{ppb}$. In the UT, the $\mathrm{CO}$ biases are for all models mostly below $10 \mathrm{ppb}$, i.e. about $10 \%$. C-IFS has overall the smallest CO bias, whereas REAN tends to overestimate and MOZ to underestimate CO over Europe and North America.

CO observed by MOZAIC over Windhoek (Fig. 9, middle) has a pronounced maximum in September because of the seasonality of biomass burning in this region. Although all runs show increased $\mathrm{CO}$ in this period, the models without assimilation were less able to reproduce the high observed $\mathrm{CO}$ values and are biased low up to $40 \mathrm{ppb}$ in LT and MT. Biases were much reduced, i.e. mostly within $10 \mathrm{ppb}$, during the rest of the year. The assimilation in REAN greatly reduces the bias in the biomass burning period. In UT, C-IFS had slightly smaller biases of about $10 \mathrm{ppb}$ than $\mathrm{MOZ}$ and REAN. A less complete record of the seasonal variability is available for Caracas (Fig. 9, left). All models tend to underestimate UT and MT CO maxima in April by about $20 \%$ but, in contrast to Windhoek, the C-IFS and not REAN has the smallest bias in LT. Hyderabad (Fig. 9, right) is the only observation site were a substantial overestimation of $\mathrm{CO}$ in LT and UT is present even though the observations are in the range of $150-250 \mathrm{ppb}$, which is mostly higher than at any of the other airports discussed. All models overestimate the seasonality because of an underestimation in JJA and an overestimation during the rest of the year.

The outcome of the comparison with LT $\mathrm{CO}$ from MOZAIC is consistent with the model bias with respect to the GAW surface observations in Europe (Fig. 10). The winter biases were larger than summer biases and MOZ showed the largest underestimation. The GAW stations measuring $\mathrm{CO}$ are mostly located on mountains in the Alpine region and typical annual biases were about $-5,-20$ and $-35 \mathrm{ppb}$ for 

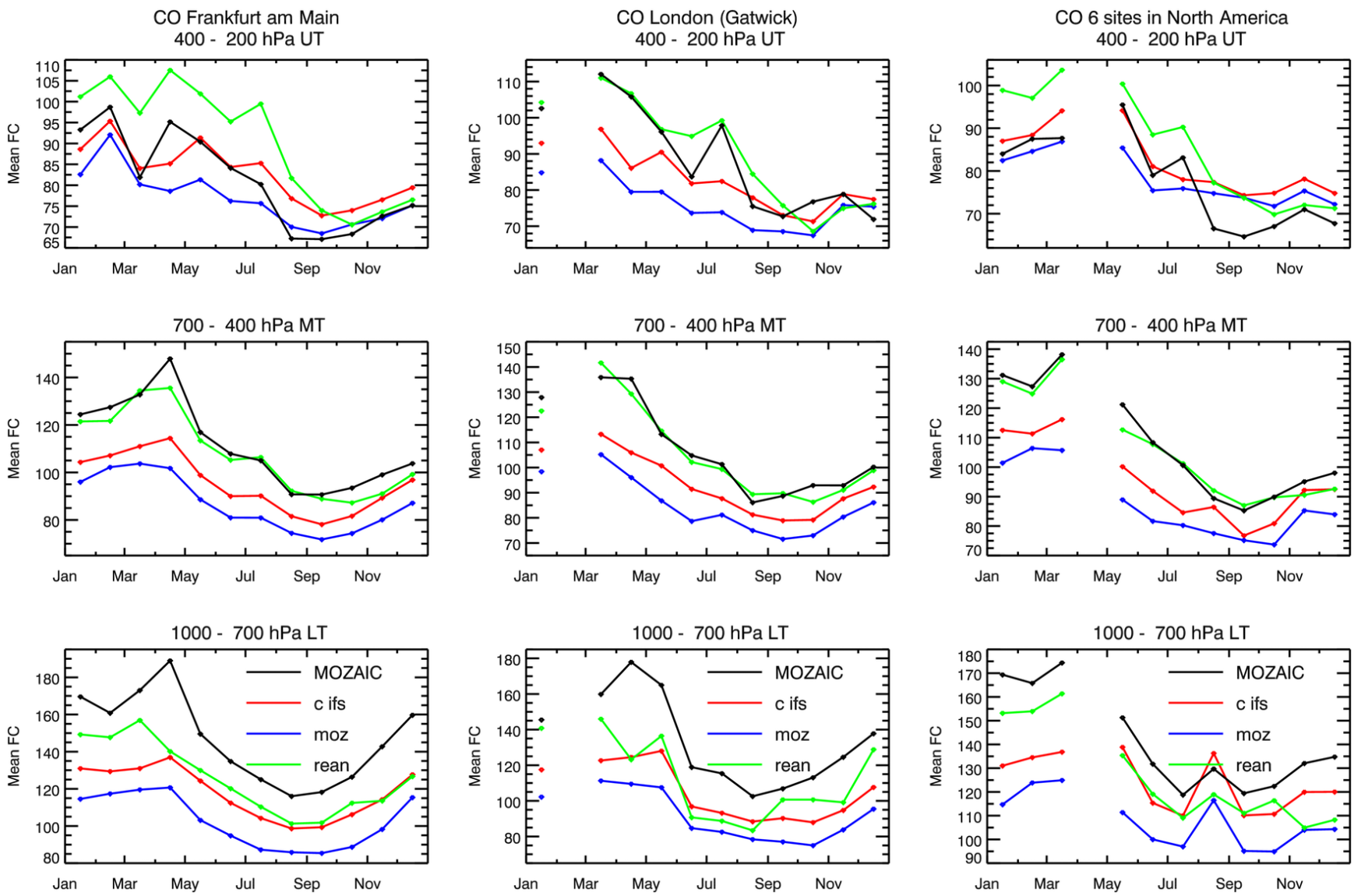

Figure 8. CO volume mixing ratios (ppb) over Frankfurt (left), London (middle) and North America (left, averaged over six airports) averaged in the pressure bands $1000-700 \mathrm{hPa}$ (bottom), 700-400 hPa (middle) and 400-200 hPa (top) observed by MOZAIC and simulated by C-IFS (red), MOZ (blue) and REAN (green) in 2008.

REAN, C-IFS and MOZ, respectively. The negative biases of stations in flatter terrain such as Kollumerward tended to be larger.

\subsection{Nitrogen dioxide}

The global maxima of $\mathrm{NO}_{2}$ are located in areas of high anthropogenic and biomass burning NO emissions. The global annual distribution of annual tropospheric columns retrieved from the GOME-2 instrument and simulated by the models is shown in Fig. 11. C-IFS, MOZ and REAN showed a very similar distribution, which can be explained by that fact that the same NO emission data were used in all runs. The global patterns of the modelled fields resemble the observed annual patterns to a large extent. But the models tend to underestimate the high observed values in East Asia and Europe and also simulate too little $\mathrm{NO}_{2}$ in larger areas of medium observed $\mathrm{NO}_{2}$ levels in Asia and central Africa as well as in the outflow areas over the western Atlantic and western Pacific Ocean. This could mean that NO emissions in the most polluted areas are too low but also that the simulated lifetime of $\mathrm{NO}_{2}$ is too short. Furthermore, an insufficient simulation of $\mathrm{NO}_{\mathrm{x}}$ reservoir species such as PAN and the lack of alkyl nitrates in CB05 might be the reason for the underestimation.

The validation of the seasonality of $\mathrm{NO}_{2}$ (Fig. 12) for different regions and months shows that tropospheric $\mathrm{NO}_{2}$ columns over Europe, North America, South Africa and East Asia are reasonably reproduced. The models tend to underestimate tropospheric columns over Europe in summer (see Table 2 for area descriptions). However, the evaluation with GAW surface stations mainly from central and eastern Europe (Fig. 13) revealed an overestimation by all models in winter and a small overestimation in summer for REAN and C-IFS. All runs significantly underestimate the annual cycle of the GOME-2 $\mathrm{NO}_{2}$ tropospheric columns over East Asia. The winter-time values are only half of the observations, whereas in summer, models agree well with observations. In southern Africa $\left(20 / 0^{\circ} \mathrm{S} / 15 / 15^{\circ} \mathrm{W}\right)$, the models overestimate the increased $\mathrm{NO}_{2}$ values in the biomass burning season by a factor of 2 but show good agreement with observations in the rest of the year. The overestimation during biomass burning events could be related to the assumed NO emission factor. 

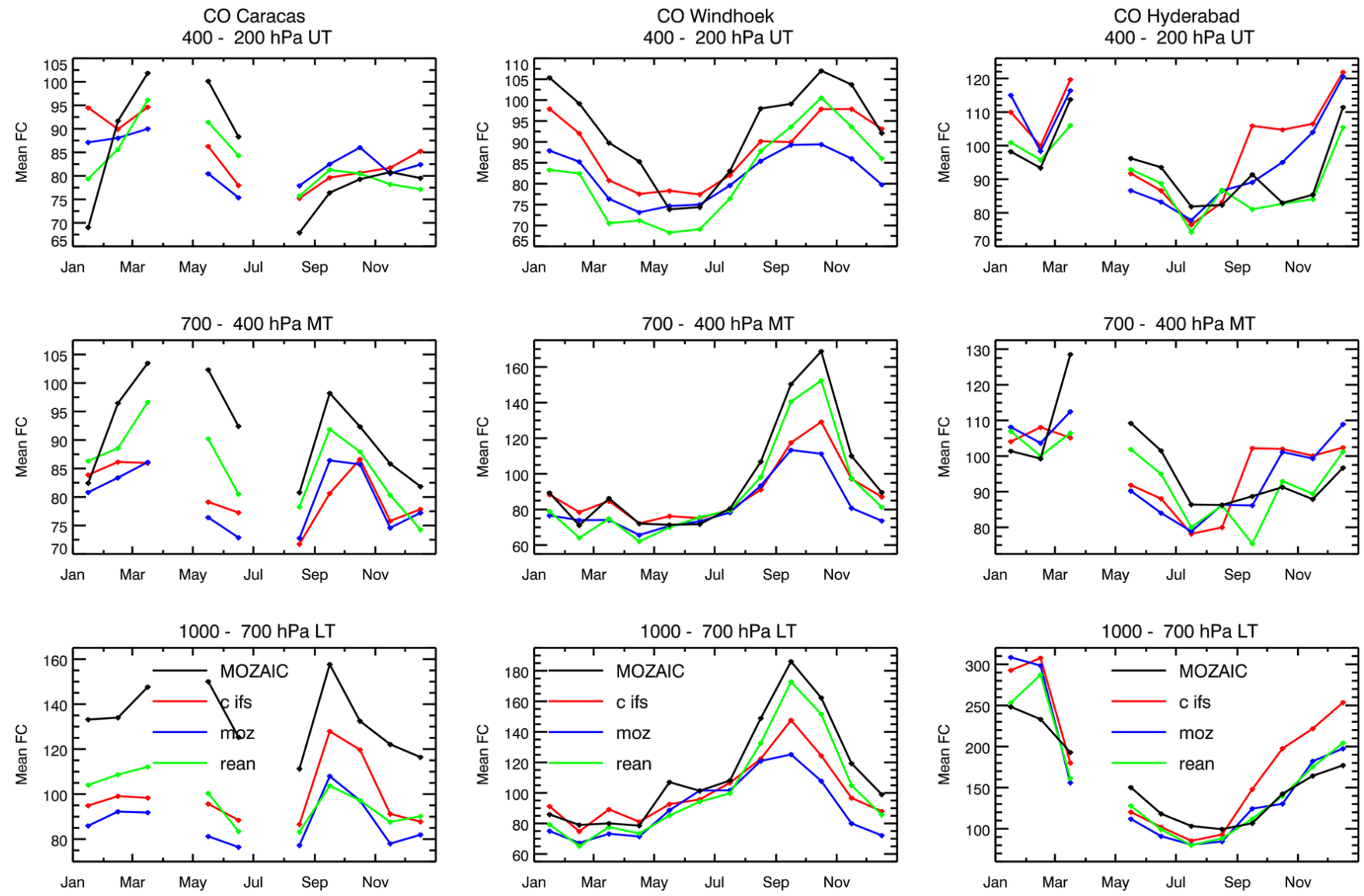

Figure 9. CO volume mixing ratios (ppb) over Caracas (left), Windhoek (middle) and Hyderabad (right), averaged in the pressure bands 1000-700 hPa (bottom), 700-400 hPa (middle) and 400-200 hPa (top) observed by MOZAIC, and simulated by C-IFS (red), MOZ (blue) and REAN (green) in 2008.

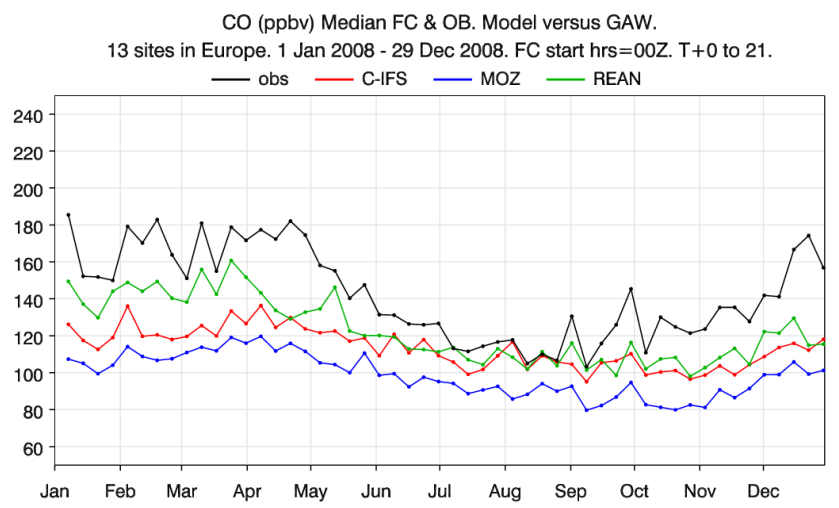

Figure 10. Time series of the median of weekly CO surface volume mixing ratios (ppb) in Europe (13 GAW sites) and model results of C-IFS, MOZ and REAN.

\subsection{HCHO}

On the global scale, $\mathrm{HCHO}$ is mainly chemically produced by the oxidation of isoprene and $\mathrm{CH}_{4}$. Isoprene is emitted by vegetation. On the regional scale, $\mathrm{HCHO}$ emissions from anthropogenic sources, vegetation and biomass burning also contribute to the $\mathrm{HCHO}$ burden.

The annual average of tropospheric $\mathrm{HCHO}$ retrieved from GOME-2 and from the model runs is shown in Fig. 14. The observations show higher values in the tropics and the $\mathrm{NH}$ and maxima in the rain forest regions of South America and central Africa and in Southeast Asia. The simulated fields of the three runs are very similar. C-IFS, MOZ and REAN reproduce the observed global patterns but show a small but widespread underestimation in the $\mathrm{NH}$ extratropics and in industrialised East Asia. On the other hand, $\mathrm{HCHO}$ is overestimated in Indonesia. Figure 15 shows model time series of tropospheric $\mathrm{HCHO}$ against corresponding GOME-2 satellite retrievals for selected regions. The models underestimated satellite values over East Asia, especially in summer, and overestimate $\mathrm{HCHO}$ columns for Indonesia $\left(5^{\circ} \mathrm{S} / 5^{\circ} \mathrm{N} / 100 / 120^{\circ} \mathrm{E}\right)$ throughout the year. The seasonality in southern Africa (not shown) and tropical South America $\left(10 / 5^{\circ} \mathrm{S} / 73 / 35^{\circ} \mathrm{W}\right)$ is well captured, in particular by C-IFS. All models also reproduced the observations rather well for 

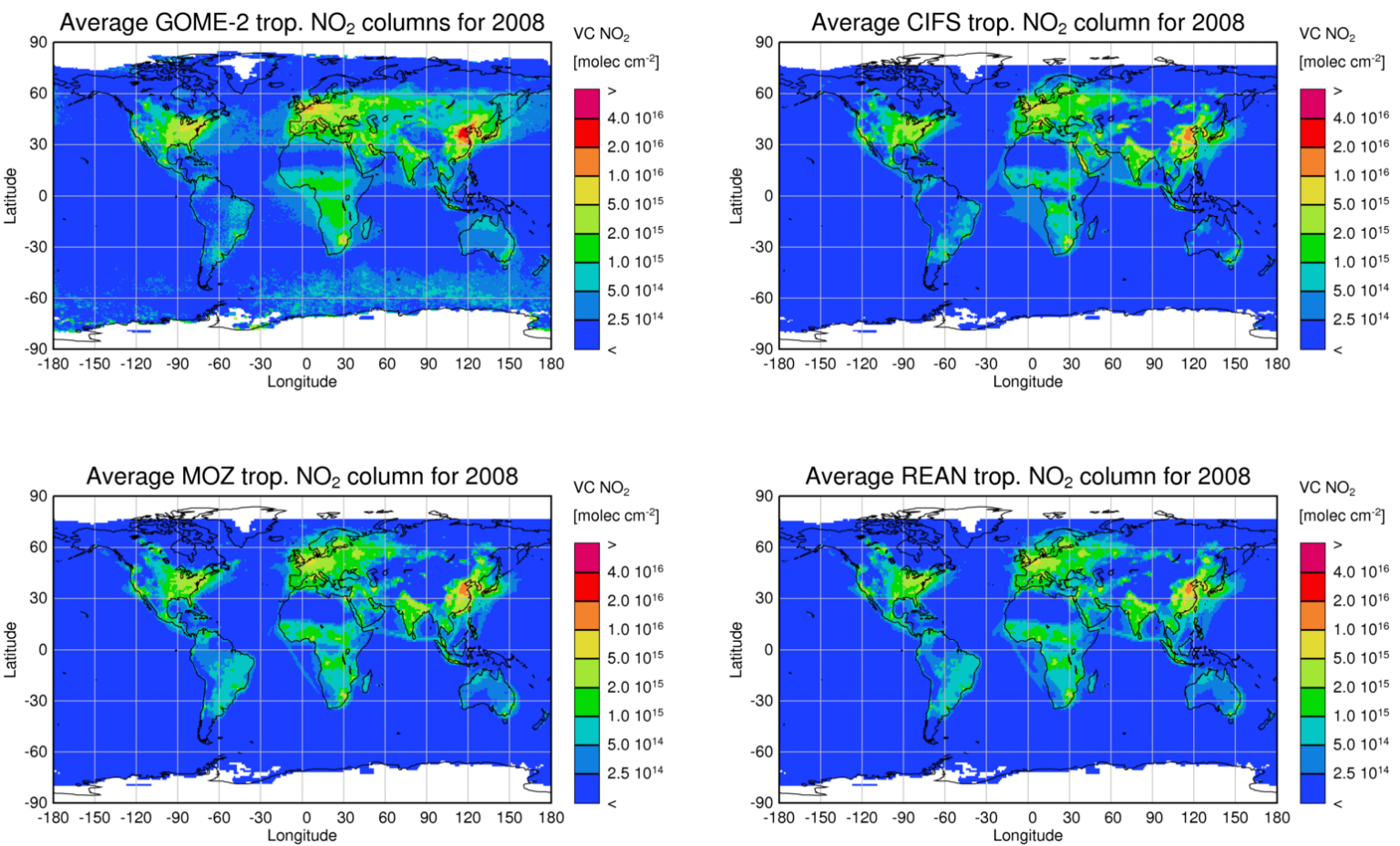

Figure 11. $\mathrm{NO}_{2}$ tropospheric column retrieval (GOME-2) for 2008 (top left) and by C-IFS (top right), REAN (bottom right) and MOZ (bottom left).
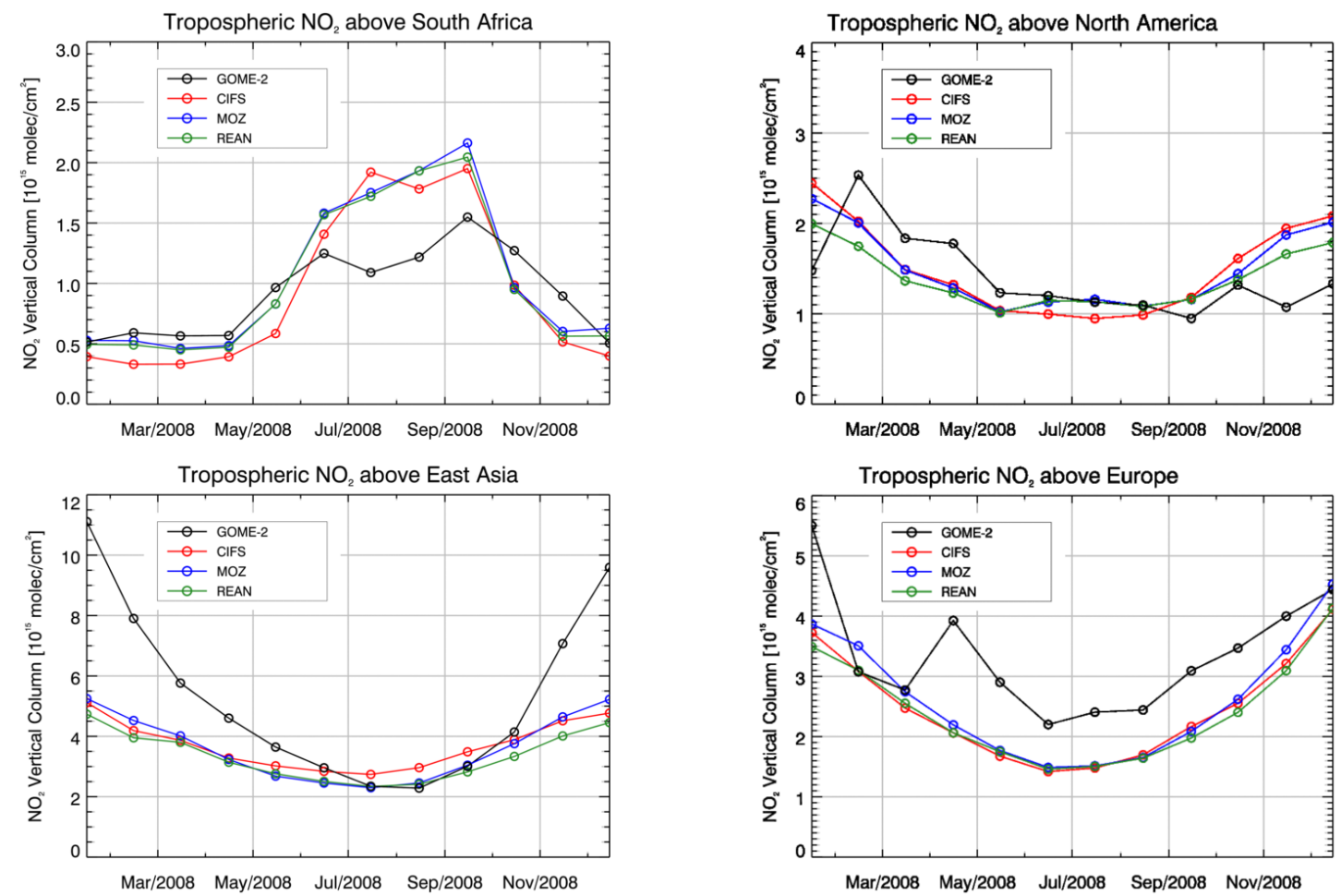

Figure 12. Time series of area-averaged tropospheric $\mathrm{NO}_{2}$ columns $\left(10^{15}\right.$ molec $\left.\mathrm{cm}^{-2}\right)$ from GOME-2 compared to model results of C-IFS (CB05) (blue), MOZ (red) and REAN (green) for different regions. 


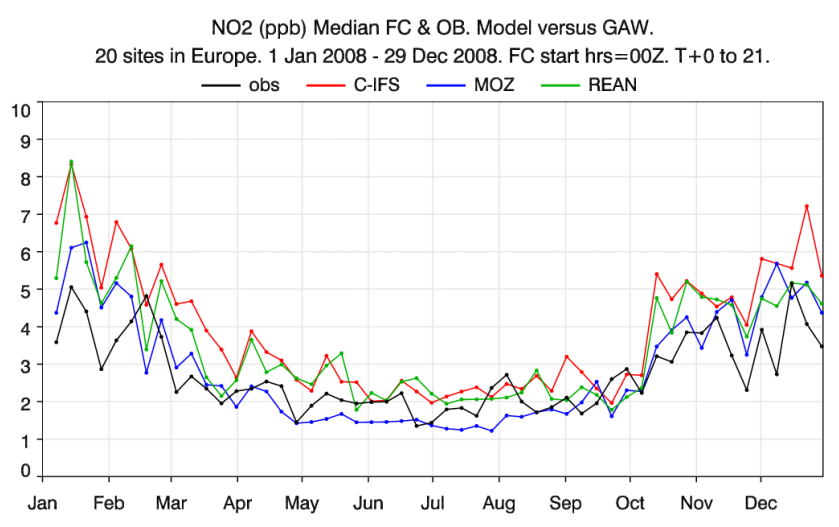

Figure 13. Time series of the median of weekly surface $\mathrm{NO}_{2}$ volume mixing ratios (ppb) in Europe (20 GAW sites) and model results of C-IFS, MOZ and REAN.

the eastern United States $\left(30 / 40^{\circ} \mathrm{N} / 90 / 75^{\circ} \mathrm{W}\right)$, but tend to underestimate wintertime $\mathrm{HCHO}$ columns for this region.

\subsection{Sulfur dioxide}

$\mathrm{SO}_{2}$ was evaluated with available GAW surface observations from central and eastern Europe. There were considerable differences in the performance for individual stations often caused by local effects not resolved by the models. To summarise the evaluation for $\mathrm{SO}_{2}$, Fig. 16 shows the median of weekly observed and modelled time series. REAN and MOZ greatly exaggerated the seasonal cycle since the values in winter were up to 8 times larger than the median of the observations. The summer values of the two runs were about $50 \%$ higher than the observations. C-IFS followed better the weak seasonality of the observations, but suffered from a nearly constant bias of about $1 \mathrm{ppb}(100 \%)$, which was much smaller than the bias of REAN and MOZ in winter, but slightly higher in summer. Overall, the on-line integration of C-IFS showed lower $\mathrm{SO}_{2}$ biases.

As no $\mathrm{SO}_{2}$ observations were assimilated in REAN and identical $\mathrm{SO}_{2}$ emissions were used, the differences between the runs were caused by differences in the simulation of vertical mixing, sulfur chemistry and wet and dry deposition in CIFS and MOZART. The winter-time bias of REAN and MOZ could be introduced by the diffusion scheme in MOZART.

\subsection{Computational cost}

The computational cost is an important factor for the operational applications in CAMS. The computational costs of different configurations of IFS, C-IFS and IFS-MOZART are given in Table 3. Computational cost is expressed in billing units (BU) of the ECMWF IBM Power 7 super-computer. BUs are proportional to the number of used central processing units (CPU) times the simulation time.

The increase in cost because of the simulation of the CB05 chemistry with respect to an NWP run is a factor of about 4 at resolutions T159 $(110 \mathrm{~km}), \mathrm{T} 255(80 \mathrm{~km})$ and T511 $(40 \mathrm{~km})$. C-IFS (CB05) is about 8 times more efficient than the IFSMOZART coupled system at a T159 resolution and about 15 times more at a T255 resolution. This strong relative increase in cost of IFS-MOZART is caused by the increasing memory requirements of the IFS at higher resolution, or also in data assimilation mode. However, there is insufficient parallelism in MOZART to exploit the larger number of CPUs for speeding up the simulation of the coupled system.

C-IFS with the MOZART chemical mechanism, i.e. the same chemistry scheme as in IFS-MOZART, is about 2 times and C-IFS with RACMOBUS 7 times more costly than C-IFS (CB05) at a T159 resolution. Both the MOZART and RACMOBUS schemes encompass a larger number of species and reactions and include a full stratospheric chemistry scheme, which is missing in CB05. The overhead because of the doubled number of advected species in C-IFS RACMOBUS and MOZART is however small because of the efficiency of the SL advection scheme.

\section{Summary and outlook}

Modules for the simulation of atmospheric chemistry have been implemented on-line in the Integrated Forecasting System (IFS) of ECMWF. The chemistry scheme complements the already integrated modules for aerosol and greenhouse gases as part of the IFS for atmospheric composition (C-IFS). C-IFS for chemistry replaces the IFS-MOZART coupled system for forecast and assimilation of reactive gases within the pre-operational Copernicus Atmosphere Monitoring Service.

C-IFS applies the CB05 chemical mechanism, which describes tropospheric chemistry with 55 species and 126 reactions. C-IFS benefits from the detailed cloud and precipitation physics of the IFS for the calculation of wet deposition and lightning NO emission. Wet deposition modelling is based on Jacob (2000) and accounts for the sub-gridscale distribution of clouds and precipitation. Dry deposition is modelled using pre-calculated monthly mean dry deposition velocities following Wesely (1989) with a superimposed diurnal cycle. Surface emissions and dry deposition fluxes are applied as surface boundary conditions of the diffusion scheme. Lightning emissions of NO can be calculated either by cloud height (Price and Rind, 1993) or by convective precipitation (Meijer et al., 2001). The latter parameterisation was used in this study. The anthropogenic emissions were taken from the MACCity inventory and biomass burning emissions from the GFAS data set for 2008.

An evaluation for the troposphere of a simulation in 2008 with C-IFS (CB05) and the MOZART CTM (MOZ) as well as with the MACC re-analysis (REAN) was carried out. The model results were compared against ozonesondes, MOZAIC CO aircraft profiles, European surface observations of $\mathrm{O}_{3}, \mathrm{CO}, \mathrm{SO}_{2}$ and $\mathrm{NO}_{2}$, and global satellite retrievals of $\mathrm{CO}, \mathrm{NO}_{2}$ and $\mathrm{HCHO}$. The evaluation showed that C-IFS 

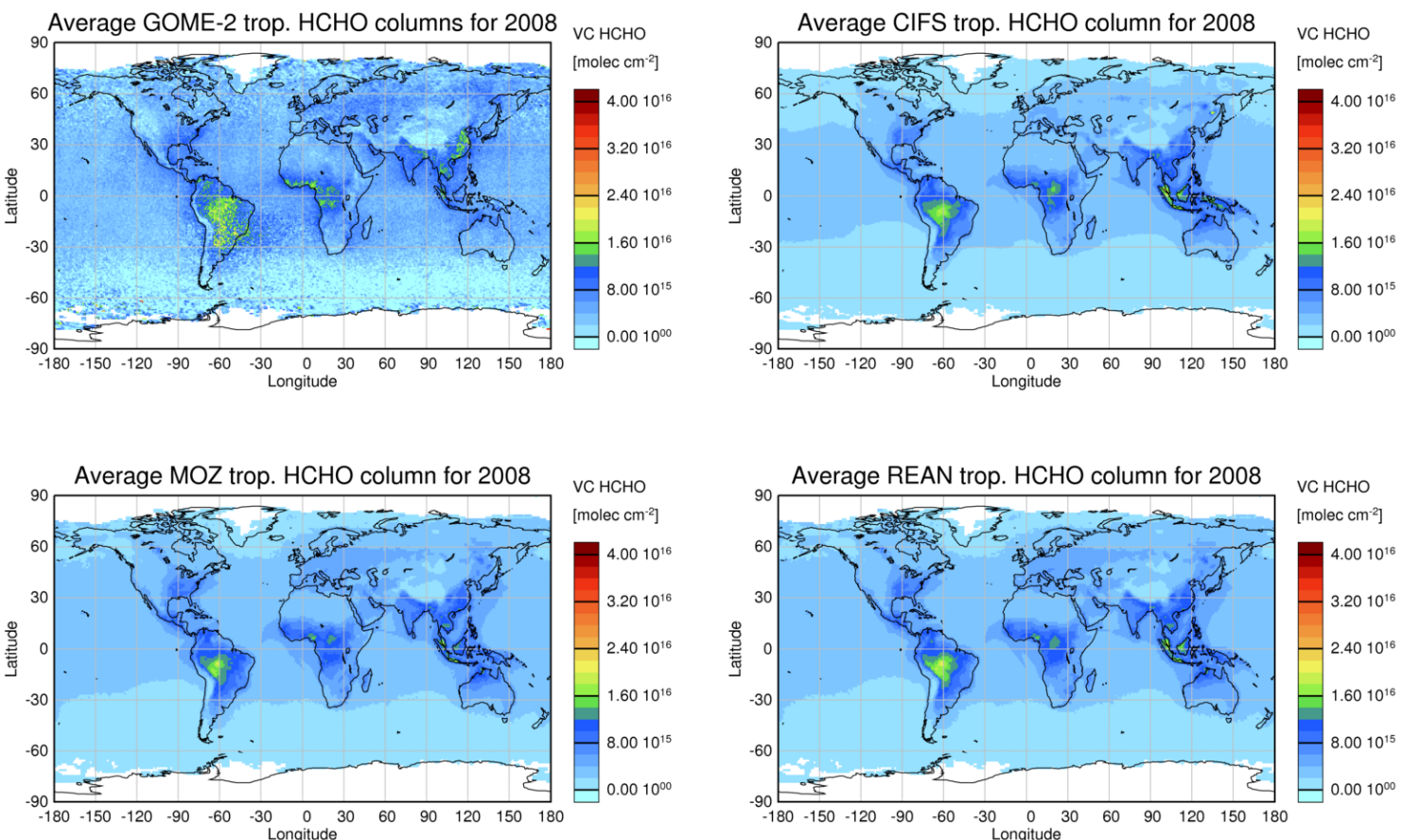

Figure 14. HCHO tropospheric column retrieval (GOME-2) for 2008 (top left) and by C-IFS (top right), REAN (bottom right) and MOZ (bottom left).
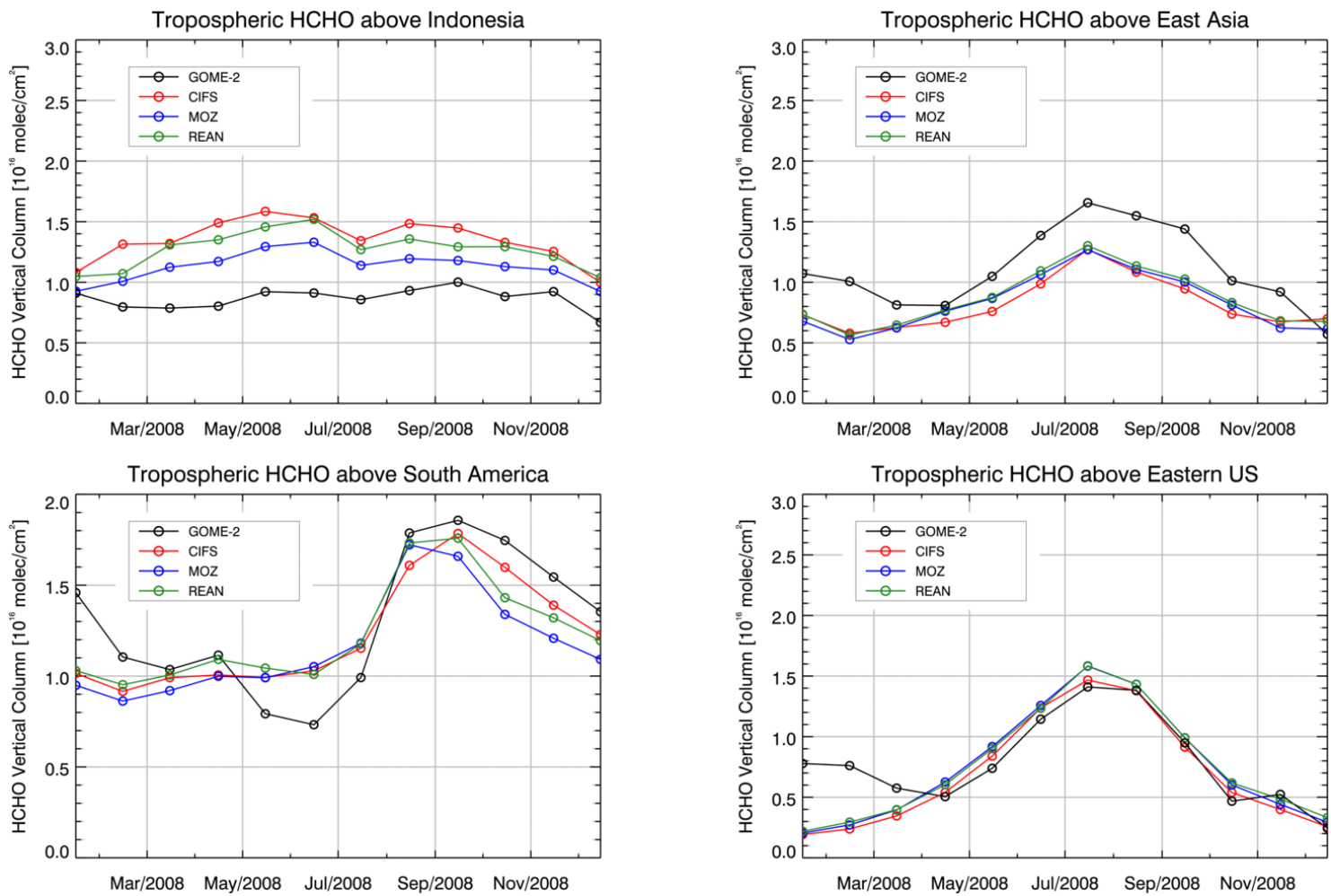

Figure 15. Time series of area-averaged tropospheric HCHO columns $\left(10^{16} \mathrm{molec} \mathrm{cm}^{-2}\right)$ from GOME-2 compared to model results of C-IFS, MOZ and REAN for different regions. 
Table 3. Computational cost (BU) of $24 \mathrm{~h}$ forecasts of different horizontal model resolutions (60 levels) and chemistry schemes of C-IFS, IFS-MOZART and IFS, *not fully optimised.

\begin{tabular}{lccccc}
\hline Resolution & IFS-MOZART & C-IFS (MOZART)* & C-IFS (MOCAGE)* & C-IFS (CB05) & IFS \\
\hline T159 & 205 & 56 & 147 & 20 & 6 \\
T255 & 1200 & - & - & 55 & 12 \\
T511 & - & - & - & 700 & 125 \\
\hline
\end{tabular}

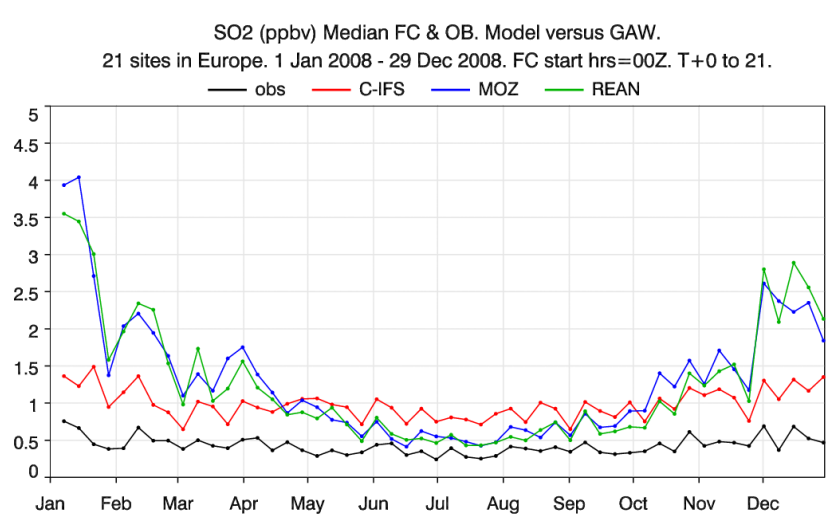

Figure 16. Time series of the median of weekly surface $\mathrm{SO}_{2}$ volume mixing ratios (ppb) in Europe (21 GAW sites) and model results of C-IFS, MOZ and REAN.

preforms better or with similar accuracy as MOZART and is mostly of a similar quality as the MACC re-analysis. It should be noted that satellite retrievals of $\mathrm{CO}, \mathrm{O}_{3}$ and $\mathrm{NO}_{2}$ were assimilated into the MACC re-analysis to improve the realism of the fields simulated by IFS-MOZART.

In comparison to MOZ, C-IFS (CB05) had smaller biases (i) for $\mathrm{CO}$ in the Northern Hemisphere, (ii) for $\mathrm{O}_{3}$ in the upper troposphere and (iii) for winter-time $\mathrm{SO}_{2}$ at the surface in Europe. Furthermore, the diurnal cycle of surface $\mathrm{O}_{3}$, tested with rural European Air quality observations, showed greater realism in the C-IFS simulation. As both models used the same emission data, the improvements can be explained by the differences in the chemical mechanism and the simulation of wet and dry deposition. However, the improvements in $\mathrm{SO}_{2}$ and the diurnal cycle of $\mathrm{O}_{3}$ are most probably caused by the more consistent interplay of diffusion and sink and sources processes in the on-line integrated C-IFS.

There is still room for improvement of C-IFS (CB05). It underestimated surface $\mathrm{O}_{3}$ over Europe and North America in spring and overestimated it in late summer and autumn. $\mathrm{CO}$ was still underestimated by C-IFS in particular in Europe and North America throughout the year but more in spring and winter, and in the biomass burning season in Africa. Winter-time tropospheric $\mathrm{NO}_{2}$ over China as retrieved from the GOME-2 instrument was 2 times higher than the fields modelled by C-IFS, MOZART and the MACC re-analysis.

Although only one chemical mechanism is described in the paper, C-IFS is a model that can apply multiple chemistry schemes. The implementation of the chemistry schemes of CTMs MOCAGE and MOZART has technically been completed but further optimisation and evaluation is required. Both schemes offer a description of stratospheric chemistry, which is not included in the tropospheric scheme CB05. For this reason it is intended to combine the CB05 mechanism with the BASCOE stratospheric mechanism. An intercomparison of the performance of the different chemical mechanism is planned.

It is foreseen to further improve the link between the physics and chemistry packages in IFS. For example, the detailed information from the IFS surface scheme will be utilised for the calculation of dry deposition and biogenic emissions. A first important step is to replace the climatological dry deposition velocities with on-line calculated values. Furthermore, the impact of the simulated $\mathrm{O}_{3}$ fields, once the stratospheric chemistry is fully implemented, on the IFS radiation scheme and the corresponding feedback on the temperature fields will be investigated.

Another ongoing development is to link more closely the greenhouse gas, aerosol and gas-phase chemistry modules of C-IFS. Relevant chemical conversion terms can already be fed to the GLOMAP aerosol (Mann et al., 2010) module for the simulation of secondary aerosols. The calculation of photolysis rates can account for the presence of aerosols, and $\mathrm{HO}_{2}$ uptake on aerosols can be simulated (Huijnen et al., 2014).

In summary, C-IFS is a new global chemistry weather model for forecast and assimilation of atmospheric composition. C-IFS (CB05) has already been successfully applied in data assimilation mode (Inness et al., 2015). C-IFS offers improvements over the IFS-MOZART coupled system because (i) it simulates several trace gas C-IFS (CB05)es with better accuracy, (ii) it is computational several times more efficient in particular at high resolution and (iii) it better facilitates the implementation of feedback processes between gas-phase and aerosol processes as well as between atmospheric composition and meteorology.

\section{Code availability}

The C-IFS source code is integrated into ECWMF's IFS code, which is only available subject to a licence agreement with ECMWF. ECMWF member-state weather services and their approved partners will get access granted. The IFS code without modules for assimilation 
and chemistry can be obtained for educational and academic purposes as part of the openIFS release (https:// software.ecmwf.int/wiki/display/OIFS/OpenIFS+Home). A detailed documentation of the IFS code is available from https://software.ecmwf.int/wiki/display/IFS/CY40R1+ Official+IFS+Documentation. The CB05 chemistry module of C-IFS was originally developed in the TM5 chemistrytransport model. Readers interested in the TM5 code can contact the TM5 developers (http://tm5.sourceforge.net) or can go directly to the TM5 wiki page, http://tm.knmi.nl/index. php/Main_Page.

\section{The Supplement related to this article is available online at doi:10.5194/gmd-8-975-2015-supplement.}

Acknowledgements. MACC II is funded by the European Union's Seventh Framework Programme (FP7) under grant agreement no. 283576. The MOPITT data were obtained from the NASA Langley Research Atmospheric Science Data Center. We are grateful to the World Ozone and Ultraviolet Radiation Data Centre (WOUDC) for providing ozonesonde observations. We thank the Global Atmospheric Watch programme for the provision of $\mathrm{NO}_{2}, \mathrm{CO}$ and $\mathrm{SO}_{2}$ surface observations. We thank the European Environmental Agency for providing access to European $\mathrm{O}_{3}$ observations in the AirBase database. We also thank the MOZAIC (Measurements of OZone, water vapour, carbon monoxide and nitrogen oxides by in-service AIrbus aircraft) and IAGOS (In-Service Aircraft for a Global Observing System) programmes for providing CO profile observations.

Edited by: F. O'Connor

\section{References}

Archibald, A. T., Cooke, M. C., Utembe, S. R., Shallcross, D. E., Derwent, R. G., and Jenkin, M. E.: Impacts of mechanistic changes on $\mathrm{HO}_{\mathrm{x}}$ formation and recycling in the oxidation of isoprene, Atmos. Chem. Phys., 10, 8097-8118, doi:10.5194/acp-108097-2010, 2010.

Arnold, S. R., Emmons, L. K., Monks, S. A., Law, K. S., Ridley, D. A., Turquety, S., Tilmes, S., Thomas, J. L., Bouarar, I., Flemming, J., Huijnen, V., Mao, J., Duncan, B. N., Steenrod, S., Yoshida, Y., Langner, J., and Long, Y.: Biomass burning influence on high latitude tropospheric ozone and reactive nitrogen in summer 2008: a multi-model analysis based on POLMIP simulations, Atmos. Chem. Phys. Discuss., 14, 24573-24621, doi:10.5194/acpd-14-24573-2014, 2014.

Atkinson, R., Baulch, D. L., Cox, R. A., Crowley, J. N., Hampson, R. F., Hynes, R. G., Jenkin, M. E., Rossi, M. J., and Troe, J.: Evaluated kinetic and photochemical data for atmospheric chemistry: Volume I - gas phase reactions of $\mathrm{O}_{\mathrm{x}}, \mathrm{HO}_{\mathrm{x}}, \mathrm{NO}_{\mathrm{x}}$ and $\mathrm{SO}_{\mathrm{x}}$ species, Atmos. Chem. Phys., 4, 1461-1738, doi:10.5194/acp-41461-2004, 2004.
Atkinson, R., Baulch, D. L., Cox, R. A., Crowley, J. N., Hampson, R. F., Hynes, R. G., Jenkin, M. E., Rossi, M. J., Troe, J., and IUPAC Subcommittee: Evaluated kinetic and photochemical data for atmospheric chemistry: Volume II - gas phase reactions of organic species, Atmos. Chem. Phys., 6, 3625-4055, doi:10.5194/acp-6-3625-2006, 2006.

Baklanov, A., Schlünzen, K., Suppan, P., Baldasano, J., Brunner, D., Aksoyoglu, S., Carmichael, G., Douros, J., Flemming, J., Forkel, R., Galmarini, S., Gauss, M., Grell, G., Hirtl, M., Joffre, S., Jorba, O., Kaas, E., Kaasik, M., Kallos, G., Kong, X., Korsholm, U., Kurganskiy, A., Kushta, J., Lohmann, U., Mahura, A., Manders-Groot, A., Maurizi, A., Moussiopoulos, N., Rao, S. T., Savage, N., Seigneur, C., Sokhi, R. S., Solazzo, E., Solomos, S., Sørensen, B., Tsegas, G., Vignati, E., Vogel, B., and Zhang, Y.: Online coupled regional meteorology chemistry models in Europe: current status and prospects, Atmos. Chem. Phys., 14, 317-398, doi:10.5194/acp-14-317-2014, 2014.

Bândă, N., Krol, M., van Noije, T., van Weele, M., Williams, J. E., Le Sager, P., Niemeier, U., Thomason, L., and Röckmann, T.: The effect of stratospheric sulfur from Mount Pinatubo on tropospheric oxidizing capacity and methane, J. Geophys. Res. Atmos., 119, 1202-1220, doi:10.1002/2014JD022137, 2015.

Bechtold, P., Semane, N., Lopez, P., Chaboureau, J.-P., Beljaars, A., and Bormann, N.: Representing Equilibrium and Nonequilibrium Convection in Large-Scale Models, J. Atmos. Sci., 71, 734-753, doi:10.1175/JAS-D-13-0163.1, 2014.

Beekmann, M., Ancellet, G., Megie, G., Smit, H. G. J., and Kley, D.: Intercomparison campaign for vertical ozone profiles including electrochemical sondes of ECC and Brewer-Mast type and aground based UV-differential absorption radar, J. Atmos. Chem., 10, 259-288, 1994.

Beljaars, A. and Viterbo, P.: The role of the boundary layer in a numerical weather prediction model, in: Clear and cloudy boundary layers, edited by: Holtslag, A. A. M. and Duynkerke, P., Royal Netherlands Academy of Arts and Sciences, p. 287-304, North Holland Publishers, Amsterdam, 1998.

Beljaars, A., Bechtold, P., Kohler, M., Morcrette, J.-J., Tompkins, A., Viterbo, P., and Wedi, N.: The numerics of physical parameterization, Seminar on Recent developments in numerical methods for atmospheric and ocean modelling, 610 September, available at: http://old.ecmwf.int/publications/ library/do/references/list/17334 (last access: 29 March 2015), 2004.

Benedetti, A., Morcrette, J.-J., Boucher, O., Dethof, A., Engelen, R. J., Fisher, M., Flentje, H., Huneeus, N., Jones, L., Kaiser, J. W., Kinne, S., Mangold, A., Razinger, M., Simmons, A. J., Suttie, M., and the GEMS-AER team: Aerosol analysis and forecast in the European Centre for Medium-Range Weather Forecasts Integrated Forecast System: 2. Data assimilation, J. Geophys. Res., 114, D13205, doi:10.1029/2008JD011115, 2009.

Bousserez, N., Attié, J.-L., Peuch, V.-H., Michou, M., and Pfister, G.: Evaluation of the MOCAGE chemistry and transport model during the ICARTT/ITOP experiment, J. Geophys. Res., 112, D10S42, doi:10.1029/2006JD007595, 2007.

Callies, J., Corpacicioli, E., Eisinger, M., Hahne, A., and Lefebvre, A.: GOME-2 Metops's Second Generation Sensor for Operational Ozone Monitoring, ESA Bulletin, 102, 28-36, 2000.

Cariolle, D. and Teyssèdre, H.: A revised linear ozone photochemistry parameterization for use in transport and general circulation 
models: multi-annual simulations, Atmos. Chem. Phys., 7, 21832196, doi:10.5194/acp-7-2183-2007, 2007.

Cecil, D. J., Buechler, D. E., and Blakeslee, R. J.: Gridded lightning climatology from TRMM-LIS and OTD: Dataset description, Atmos. Res., 135-136, 404-414, doi:10.1016/j.atmosres.2012.06.028, 2012.

Chin, M., Jacob, D. J., Gardner, G. M., Foreman-Fowler, M. S., Spiro, P. A., and Savoie, D. L.: A global three-dimensional model of tropospheric sulfate, J. Geophys. Res., 101, 18667-18690, 1996

DeCaria, A. J., Pickering, K. E., Stenchikov, G. L., and Ott, L. E.: Lightning-generated $\mathrm{NO}_{\mathrm{x}}$ and its impact on tropospheric ozone production: A three-dimensional modeling study of a Stratosphere-Troposphere Experiment: Radiation, Aerosols and Ozone (STERAO-A) thunderstorm, J. Geophys. Res., 110, D14303, doi:10.1029/2004JD005556, 2005.

Dee, D. P., Uppala, S. M., Simmons, A. J., Berrisford, P., Poli, P., Kobayashi, S., Andrae, U., Balmaseda, M. A., Balsamo, G., Bauer, P., Bechtold, P., Beljaars, A. C. M., van de Berg, L., Bidlot, J., Bormann, N., Delsol, C., Dragani, R., Fuentes, M., Geer, A. J., Haimberger, L., Healy, S. B., Hersbach, H., Hólm, E. V., Isaksen, L., Kållberg, P., Köhler, M., Matricardi, M., Mcnally, A. P., Monge-Sanz, B. M., Morcrette, J.-J., Park, B.-K., Peubey, C., de Rosnay, P., Tavolato, C., Thépaut, J.-N., and Vitart, F.: The ERA-Interim reanalysis: Configuration and performance of the data assimilation system, Q. J. Roy. Meteorol. Soc., 137, 553597, 2011.

Deeter, M. N.: MOPITT Version 6 Product User's Guide, Technical Report, NCAR, Boulder, USA, 2013.137 (656), pp. 553-597, 2013.

Deeter, M. N., Martínez-Alonso, S., Edwards, D. P., Emmons, L. K., Gille, J. C., Worden, H. M., Pittman, J. V., Daube, B. C., and Wofsy, S. C.: Validation of MOPITT Version 5 thermalinfrared, near-infrared, and multispectral carbon monoxide profile retrievals for 2000-2011, J. Geophys. Res.-Atmos., 118, 6710-6725, doi:10.1002/jgrd.50272, 2013.

Dentener, F. J. and Crutzen, P. J.: Reaction of $\mathrm{N}_{2} \mathrm{O}_{5}$ on tropospheric aerosols: Impact on the global distributions of $\mathrm{NO}_{\mathrm{x}}, \mathrm{O}_{3}$ and $\mathrm{OH}$, J. Geophys. Res., 98, 7149-7163, 1993.

Diamantakis, M. and Flemming, J.: Global mass fixer algorithms for conservative tracer transport in the ECMWF model, Geosci. Model Dev., 7, 965-979, doi:10.5194/gmd-7-965-2014, 2014.

Elguindi, N., Clark, H., Ordóñez, C., Thouret, V., Flemming, J., Stein, O., Huijnen, V., Moinat, P., Inness, A., Peuch, V.-H., Stohl, A., Turquety, S., Athier, G., Cammas, J.-P., and Schultz, M.: Current status of the ability of the GEMS/MACC models to reproduce the tropospheric $\mathrm{CO}$ vertical distribution as measured by MOZAIC, Geosci. Model Dev., 3, 501-518, doi:10.5194/gmd-3501-2010, 2010.

Emmons, L. K., Walters, S., Hess, P. G., Lamarque, J.-F., Pfister, G. G., Fillmore, D., Granier, C., Guenther, A., Kinnison, D., Laepple, T., Orlando, J., Tie, X., Tyndall, G., Wiedinmyer, C., Baughcum, S. L., and Kloster, S.: Description and evaluation of the Model for Ozone and Related chemical Tracers, version 4 (MOZART-4), Geosci. Model Dev., 3, 43-67, doi:10.5194/gmd3-43-2010, 2010.

Emmons, L. K., Arnold, S. R., Monks, S. A., Huijnen, V., Tilmes, S., Law, K. S., Thomas, J. L., Raut, J.-C., Bouarar, I., Turquety, S., Long, Y., Duncan, B., Steenrod, S., Strode, S., Flemming, J.,
Mao, J., Langner, J., Thompson, A. M., Tarasick, D., Apel, E. C., Blake, D. R., Cohen, R. C., Dibb, J., Diskin, G. S., Fried, A., Hall, S. R., Huey, L. G., Weinheimer, A. J., Wisthaler, A., Mikoviny, T., Nowak, J., Peischl, J., Roberts, J. M., Ryerson, T., Warneke, C., and Helmig, D.: The POLARCAT Model Intercomparison Project (POLMIP): overview and evaluation with observations, Atmos. Chem. Phys. Discuss., 14, 29331-29393, doi:10.5194/acpd-14-29331-2014, 2014.

Engelen, R. J., Serrar, S., and Chevallier, F.: Four-dimensional data assimilation of atmospheric CO2 using AIRS observations, J. Geophys. Res., 114, D03303, doi:10.1029/2008JD010739, 2009.

Errera, Q., Daerden, F., Chabrillat, S., Lambert, J. C., Lahoz, W. A., Viscardy, S., Bonjean, S., and Fonteyn, D.: 4D-Var assimilation of MIPAS chemical observations: ozone and nitrogen dioxide analyses, Atmos. Chem. Phys., 8, 6169-6187, doi:10.5194/acp8-6169-2008, 2008

Evans, M. J. and Jacob, D. J.: Impact of new laboratory studies of N2O5 hydrolysis on global model budgets of tropospheric nitrogen oxides, ozone, and OH, Geophys. Res. Lett., 32, L09813, doi:10.1029/2005GL022469, 2005.

Fiore, A. M., Naik, V., Spracklen, D. V., Steiner, A., Unger, N., Prather, M., Bergmann, D., Cameron-Smith, P. J., Cionni, I., Collins, W. J., Dalsoren, S., Eyring, V., Folberth, G. A., Ginoux, P., Horowitz, L. W., Josse, B., Lamarque, J.-F., MacKenzie, I. A., Nagashima, T., O'Connor, F. M., Righi, M., Rumbold, S. T., Shindell, D. T., Skeie, R. B., Sudo, K., Szopa, S., Takemura, T., and Zeng, G.: Global air quality and climate, Chem. Soc. Rev., 41, 6663-6683, 2012.

Flemming, J., Stern, R., and Yamartino, R. J.: A new air quality regime classification scheme for $\mathrm{O}_{3}, \mathrm{NO}_{2}, \mathrm{SO}_{2}$ and $\mathrm{PM}_{10}$ observations sites, Atmos. Environ., 39, 6121-6129, 2005.

Flemming, J., Inness, A., Flentje, H., Huijnen, V., Moinat, P., Schultz, M. G., and Stein, O.: Coupling global chemistry transport models to ECMWF's integrated forecast system, Geosci Model Dev., 2, 253-265, doi:10.5194/gmd-2-253-2009, 2009a.

Flemming, J., Inness, A., Flentje, H., Huijnen, V., Moinat, P., Schultz, M. G., and Stein, O.: Coupling global chemistry transport models to ECMWF's integrated forecast system ECMWF technical memorandum 590, available at: http://old.ecmwf.int/ publications/library/ecpublications/_pdf/tm/501-600/tm590.pdf (last access: 29 March 2015), 2009b.

Flemming, J. and Huijnen, V.: IFS Tracer Transport Study, MACC Deliverable G-RG 4.2, Tech. rep., ECMWF, available at: http://www.gmes-atmosphere.eu/documents/deliverables/g-rg/ ifs_transport_study.pdf (last access: 29 March 2015), 2011.

Flemming, J., Inness, A., Jones, L., Eskes, H. J., Huijnen, V., Schultz, M. G., Stein, O., Cariolle, D., Kinnison, D., and Brasseur, G.: Forecasts and assimilation experiments of the Antarctic ozone hole 2008, Atmos. Chem. Phys., 11, 1961-1977, doi:10.5194/acp-11-1961-2011, 2011.

Flemming, J., Peuch, V.-H., Engelen, R., and Kaiser, J. W.: A European Global-to-Regional Air Pollution Forecasting System that Combines Modeling with Satellite Observations, EM Magazine of A\&WMA, November 2013, pp. 6-10, available at: https://www.researchgate.net/publication/259535688_A_ European_Global-to-Regional_Air_Pollution_Forecasting_ System_that_Combines_Modeling_with_Satellite_Observations (last access: 29 March 2015), 2013. 
Forbes, R. M., Tompkins, A. M., and Untch, A.: A new prognostic bulk-microphysics scheme for the IFS. ECMWF Tech. Memo. No. 649, 2011.

Fu, Q., Yang, P., and Sun, W. B.: An accurate parametrization of the infrared radiative properties of cyrrus clouds of climate models, J. Climate, 11, 2223-2237, 1998.

Gauss, M., Isaksen, I. S. A., Lee, D. S., and Søvde, O. A.: Impact of aircraft $\mathrm{NO}_{\mathrm{x}}$ emissions on the atmosphere - tradeoffs to reduce the impact, Atmos. Chem. Phys., 6, 1529-1548, doi:10.5194/acp-6-1529-2006, 2006.

Gery, M., Whitten, G. Z., Killus, J. P., and Dodge, M. C.: A photochemical kinetics mechanism for urban and regional scale computer modelling, J. Geophys. Res., 94, 18925-18956, 1989.

Granier, C., Lamarque, J. F., Mieville, A., Muller, J. F., Olivier, J., Orlando, J., Peters, J., Petron, G., Tyndall, G., and Wallens, S.: POET, a database of surface emissions of ozone precursors, available on internet at: http://www.aero.jussieu.fr/projet/ ACCENT/POET.php (last access: 29 March 2015), 2005.

Granier, C., Bessagnet, B., Bond, T., D’Angiola, A., v. d. Gon, H. D., Frost, G. J., Heil, A., Kaiser, J. W., Kinne, S., Klimont, Z., Kloster, S., Lamarque, J.-F., Liousse, C., Masui, T., Meleux, F., Mieville, A., Ohara, T., Raut, J.-C., Riahi, K., Schultz, M. G., Smith, S. J., Thomson, A., v. Aardenne, J., v. d. Werf, G. R., and v. Vuuren, D. P.: Evolution of anthropogenic and biomass burning emissions of air pollutants at global and regional scales during the 1980-2010 period, Clim. Change, 109, 163-190, doi:10.1007/s10584-011-0154-1, 2011.

Grooß, J.-U. and Russell III, J. M.: Technical note: A stratospheric climatology for $\mathrm{O}_{3}, \mathrm{H}_{2} \mathrm{O}, \mathrm{CH}_{4}, \mathrm{NO}_{\mathrm{x}}, \mathrm{HCl}$ and $\mathrm{HF}$ derived from HALOE measurements, Atmos. Chem. Phys., 5, 2797-2807, doi:10.5194/acp-5-2797-2005, 2005.

Guenther, A., Karl, T., Harley, P., Wiedinmyer, C., Palmer, P. I., and Geron, C.: Estimates of global terrestrial isoprene emissions using MEGAN (Model of Emissions of Gases and Aerosols from Nature), Atmos. Chem. Phys., 6, 3181-3210, doi:10.5194/acp-63181-2006, 2006.

Haywood, J. M., Roberts, D. L., Slingo, A., Edwards, J. M., and Shine, K. P.: General circulation model calculations of the direct radiative forcing by anthropogenic sulfate and fossil-fuel soot aerosol, J. Climate, 10, 1562-1577, 1997.

Hertel, O., Berkowicz, R., Christensen, J., and Hov, Ø.: Test of two numerical schemes for use in atmospheric transport-chemistry models, Atmos. Environ., 27A, 2591-2611, 1993.

Hollingsworth, A., Engelen, R. J., Textor, C., Benedetti, A., Boucher, O., Chevallier, F., Dethof, A., Elbern, H., Eskes, H., Flemming, J., Granier, C., Kaiser, J. W., Morcrette, J.-J., Rayner, P., Peuch, V. H., Rouil, L., Schultz, M. G., Simmons, A. J., and The GEMS Consortium: Toward a Monitoring and Forecasting System For Atmospheric Composition: The GEMS Project, B. Am. Meteorol. Soc., 89, 1147-1164, 2008.

Hortal, M.: The development and testing of a new two-time-level semi-Lagrangian scheme (SETTLS) in the ECMWF forecast model, 128, 1671-1687, doi:10.1002/qj.200212858314, 2002.

Hortal, M. and Simmons, A. J.: Use of reduced Gaussian grids in spectral models, Mon. Weather Rev., 119, 1057-1074, 1991.

Houweling, S., Dentener, F. J., and Lelieveld, J.: The impact of nonmethane hydrocarbon compounds on tropospheric photochemistry, J. Geophys. Res., 103, 10673-10696, 1998.
Huijnen, V., Williams, J., van Weele, M., van Noije, T., Krol, M., Dentener, F., Segers, A., Houweling, S., Peters, W., de Laat, J., Boersma, F., Bergamaschi, P., van Velthoven, P., Le Sager, P., Eskes, H., Alkemade, F., Scheele, R., Nédélec, P., and Pätz, H.-W.: The global chemistry transport model TM5: description and evaluation of the tropospheric chemistry version 3.0, Geosci. Model Dev., 3, 445-473, doi:10.5194/gmd-3-445-2010, 2010.

Huijnen, V., Flemming, J., Kaiser, J. W., Inness, A., Leitão, J., Heil, A., Eskes, H. J., Schultz, M. G., Benedetti, A., Hadji-Lazaro, J., Dufour, G., and Eremenko, M.: Hindcast experiments of tropospheric composition during the summer 2010 fires over western Russia, Atmos. Chem. Phys., 12, 4341-4364, doi:10.5194/acp12-4341-2012, 2012.

Huijnen, V., Williams, J. E., and Flemming, J.: Modeling global impacts of heterogeneous loss of $\mathrm{HO}_{2}$ on cloud droplets, ice particles and aerosols, Atmos. Chem. Phys. Discuss., 14, 8575-8632, doi:10.5194/acpd-14-8575-2014, 2014.

Im, U., Bianconi, R., Solazzo, E., Kioutsioukis, I., Badia, A., Balzarini, A., Baró, R., Bellasio, R., Brunner, D., Chemel, C., Curci, G., Flemming, J., Forkel, R., Giordano, L., Jiménez- Guerrero, P., Hirtl, M., Hodzic, A., Honzak, L., Jorba, O., Knote, C., Kuenen, J. J. P., Makar, P. A., Manders-Groot, A., Neal, L., Pérez, J. L., Pirovano, G., Pouliot, G., San Jose, R., Savage, N., Schroder, W., Sokhi, R. S., Syrakov, D., Torian, A., Tuccella, P., Werhahn, J., Wolke, R., Yahya, K., Zabkar, R., Zhang, Y., Zhang, J., Hogrefe, C., and Galmarini, S.: Evaluation of operational on-line-coupled regional air quality models over Europe and North America in the context of AQMEII phase 2. Part I: Ozone, Atmos. Environ., doi:10.1016/j.atmosenv.2014.09.042, in press, 2014.

Inness, A., Baier, F., Benedetti, A., Bouarar, I., Chabrillat, S., Clark, H., Clerbaux, C., Coheur, P., Engelen, R. J., Errera, Q., Flemming, J., George, M., Granier, C., Hadji-Lazaro, J., Huijnen, V., Hurtmans, D., Jones, L., Kaiser, J. W., Kapsomenakis, J., Lefever, K., Leitão, J., Razinger, M., Richter, A., Schultz, M. G., Simmons, A. J., Suttie, M., Stein, O., Thépaut, J.-N., Thouret, V., Vrekoussis, M., Zerefos, C., and the MACC team: The MACC reanalysis: an $8 \mathrm{yr}$ data set of atmospheric composition, Atmos. Chem. Phys., 13, 4073-4109, doi:10.5194/acp-13-4073-2013, 2013.

Inness, A., Blechschmidt, A.-M., Bouarar, I., Chabrillat, S., Crepulja, M., Engelen, R. J., Eskes, H., Flemming, J., Gaudel, A., Hendrick, F., Huijnen, V., Jones, L., Kapsomenakis, J., Katragkou, E., Keppens, A., Langerock, B., de Mazière, M., Melas, D., Parrington, M., Peuch, V. H., Razinger, M., Richter, A., Schultz, M. G., Suttie, M., Thouret, V., Vrekoussis, M., Wagner, A., and Zerefos, C.: Data assimilation of satellite retrieved ozone, carbon monoxide and nitrogen dioxide with ECMWF's Composition-IFS, Atmos. Chem. Phys. Discuss., 15, 4265-4331, doi:10.5194/acpd-15-4265-2015, 2015.

Jacob, D. J., Liu, H., Mari, C., and Yantosca, R. M.: Harvard wet deposition scheme for GMI, Harvard University Atmospheric Chemistry Modeling Group, available at: http://acmg.seas.harvard.edu/geos/wiki_docs/deposition/ wetdep.jacob_etal_2000.pdf (last access: 29 March 2015), revised March 2000.

Jakob, C. and Klein, S.: A parameterization of the effects of cloud and precipitation overlap for use in general-circulation models, Q. J. Roy. Meteorol. Soc., 126, 2525-2544, 2000. 
Jung, T., Palmer, T. N., Rodwell, M. J., and Serrar, S.: Diagnosing forecast error using relaxation experiments, ECMWF Newsletter 82, ECMWF, Shinfield Park, Reading, Berkshire RG2 9AX, UK, 2008.

Kaiser, J. W., Heil, A., Andreae, M. O., Benedetti, A., Chubarova, N., Jones, L., Morcrette, J.-J., Razinger, M., Schultz, M. G., Suttie, M., and van der Werf, G. R.: Biomass burning emissions estimated with a global fire assimilation system based on observed fire radiative power, Biogeosciences, 9, 527-554, doi:10.5194/bg-9-527-2012, 2012.

Kaminski, J. W., Neary, L., Struzewska, J., McConnell, J. C., Lupu, A., Jarosz, J., Toyota, K., Gong, S. L., Côté, J., Liu, X., Chance, K., and Richter, A.: GEM-AQ, an on-line global multiscale chemical weather modelling system: model description and evaluation of gas phase chemistry processes, Atmos. Chem. Phys., 8, 3255-3281, doi:10.5194/acp-8-3255-2008, 2008.

Kinnison, D. E., Brasseur, G. P., Walters, S., Garcia, R. R., Marsh, D. R., Sassi, F., Harvey, V. L., Randall, C. E., Emmons, L., Lamarque, J. F., Hess, P., Orlando, J. J., Tie, X. X., Randel, W., Pan, L. L., Gettelman, A., Granier, C., Diehl, T., Niemeier, U., and Simmons, A. J.: Sensitivity of Chemical Tracers to Meteorological Parameters in the MOZART-3 Chemical Transport Model, J. Geophys. Res., 112, D03303, doi:10.1029/2008JD010739,2007.

Komhyr, W. D., Barnes, R. A., Borthers, G. B., Lathrop, J. A., Kerr, J. B., and Opperman, D. P.: Electrochemical concentration cell ozonesonde performance evaluation during STOIC 1989, J. Geophys. Res., 100, 9231-9244, 1995.

Lamarque, J.-F., Bond, T. C., Eyring, V., Granier, C., Heil, A., Klimont, Z., Lee, D., Liousse, C., Mieville, A., Owen, B., Schultz, M. G., Shindell, D., Smith, S. J., Stehfest, E., Van Aardenne, J., Cooper, O. R., Kainuma, M., Mahowald, N., McConnell, J. R., Naik, V., Riahi, K., and van Vuuren, D. P.: Historical (1850-2000) gridded anthropogenic and biomass burning emissions of reactive gases and aerosols: methodology and application, Atmos. Chem. Phys., 10, 7017-7039, doi:10.5194/acp10-7017-2010, 2010.

Lamarque, J.-F., Emmons, L. K., Hess, P. G., Kinnison, D. E., Tilmes, S., Vitt, F., Heald, C. L., Holland, E. A., Lauritzen, P. H., Neu, J., Orlando, J. J., Rasch, P. J., and Tyndall, G. K.: CAM-chem: description and evaluation of interactive atmospheric chemistry in the Community Earth System Model, Geosci. Model Dev., 5, 369-411, doi:10.5194/gmd-5-369-2012, 2012.

Lamarque, J.-F., Shindell, D. T., Josse, B., Young, P. J., Cionni, I., Eyring, V., Bergmann, D., Cameron-Smith, P., Collins, W. J., Doherty, R., Dalsoren, S., Faluvegi, G., Folberth, G., Ghan, S. J., Horowitz, L. W., Lee, Y. H., MacKenzie, I. A., Nagashima, T., Naik, V., Plummer, D., Righi, M., Rumbold, S. T., Schulz, M., Skeie, R. B., Stevenson, D. S., Strode, S., Sudo, K., Szopa, S., Voulgarakis, A., and Zeng, G.: The Atmospheric Chemistry and Climate Model Intercomparison Project (ACCMIP): overview and description of models, simulations and climate diagnostics, Geosci. Model Dev., 6, 179-206, doi:10.5194/gmd-6-179-2013, 2013.

Landgraf, J. and Crutzen, P. J.: An efficient method for online calculations of photolysis and heating trates, J. Atmos. Sci., 55, 863878, 1998.
Lawrence, M. G. and Crutzen, P. J.: The impact of cloud particle gravitational settling on soluble trace gas distributions, Tellus B, 50, 263-289, doi:10.1034/j.1600-0889.1998.t01-2-00005.x, 1998.

Lefever, K., van der A, R., Baier, F., Christophe, Y., Errera, Q., Eskes, H., Flemming, J., Inness, A., Jones, L., Lambert, J.C., Langerock, B., Schultz, M. G., Stein, O., Wagner, A., and Chabrillat, S.: Copernicus atmospheric service for stratospheric ozone: validation and intercomparison of four near real-time analyses, 2009-2012, Atmos. Chem. Phys. Discuss., 14, 1246112523, doi:10.5194/acpd-14-12461-2014, 2014.

Levine, S. Z. and Schwartz, S. E.: In-cloud and below-cloud scavenging of nitric acid vapor, Atmos. Environ., 16, 1725-1734, doi:10.1016/0004-6981(82)90266-9, 1982.

Liu, H., Jacob, D. J., Bey, I., and Yantosca, R. M.: Constraints from $210 \mathrm{~Pb}$ and $7 \mathrm{Be}$ on wet deposition and transport in a global threedimensional chemical tracer model driven by assimilated meteorological fields, J. Geophys. Res., 106, 12109-12128, 2001.

MACC VAL report: Validation report of the MACC reanalysis of global atmospheric composition Period, 2003-2011, available at: http://www.copernicus-atmosphere.eu/documents/maccii/ deliverables/val/MACCII_VAL_DEL_D_83.4_REAreport02_ 20130207.pdf (last access: 29 March 2015), 2013.

Mann, G. W., Carslaw, K. S., Spracklen, D. V., Ridley, D. A., Manktelow, P. T., Chipperfield, M. P., Pickering, S. J., and Johnson, C. E.: Description and evaluation of GLOMAP-mode: a modal global aerosol microphysics model for the UKCA composition-climate model, Geosci. Model Dev., 3, 519-551, doi:10.5194/gmd-3-519-2010, 2010.

Marenco, A., Thouret, V., Nédélec, P., Smit, H. G., Helten, M., Kley, D., Karcher, F., Simon, P., Law, K., Pyle, J., Poschmann, G., Von Wrede, R., Hume, C., and Cook, T.: Measurement of ozone and water vapour by Airbus in-service air-craft: The MOZAIC airborne programme, an overview, J. Geophys. Res., 103, 2563125642, 1998.

Meijer, E. W., van Velthoven, P. F. J., Brunner, D. W., Huntrieser, H., and Kelder, H.: Improvement and evaluation of the parameterization of nitrogen oxide production by lightning, Phys. Chem. Earth, Part C, 26, 577-583, 2001.

Menard, R., Chabrillat, S., and McConnel, J.: Coupled chemicaldynamical data assimilation, Final Report, ESA/ESTEC, 2007.

Metzger, S., Dentener, F., Krol, M. C., Jeuken, A., and Lelieveld, J.: Gas/aerosol partitioning 2. Global modeling results, J. Geophys. Res., 107, 4313, doi:10.1029/2001JD001103, 2002a.

Metzger, S., Dentener, F., Pandis, S., and Lelieveld, J.: Gas/aerosol partitioning, 1, A computationally efficient model, J. Geophys. Res., 107, 16, doi:10.1029/2001JD001102, 2002b.

Michou, M., Laville, P., Serça, D., Fotiadi, A., Bouchou, P., and Peuch, V.-H.: Measured and modeled dry deposition velocities over the ESCOMPTE area, Atmos. Res., 74, 89-116, 2004.

Monks, S. A., Arnold, S. R., Emmons, L. K., Law, K. S., Turquety, S., Duncan, B. N., Flemming, J., Huijnen, V., Tilmes, S., Langner, J., Mao, J., Long, Y., Thomas, J. L., Steenrod, S. D., Raut, J. C., Wilson, C., Chipperfield, M. P., Schlager, H., and Ancellet, G.: Multi-model study of chemical and physical controls on transport of anthropogenic and biomass burning pollution to the Arctic, Atmos. Chem. Phys. Discuss., 14, 2528125350, doi:10.5194/acpd-14-25281-2014, 2014. 
Morcrette, J.-J., Boucher, O., Jones, L., Salmond, D., Bechtold, P., Beljaars, A., Benedetti, A., Bonet, A., Kaiser, J. W., Razinger, M., Schulz, M., Serrar, S., Simmons, A. J., Sofiev, M., Suttie, M., Tompkins, A. M., and Untch, A.: Aerosol analysis and forecast in the ECMWF Integrated Forecast System. Part I: Forward modelling, J. Geophys. Res., 114, D06206, doi:10.1029/2008JD011235, 2009.

Morgenstern, O., Braesicke, P., O’Connor, F. M., Bushell, A. C., Johnson, C. E., Osprey, S. M., and Pyle, J. A.: Evaluation of the new UKCA climate-composition model - Part 1: The stratosphere, Geosci. Model Dev., 2, 43-57, doi:10.5194/gmd-2-432009, 2009.

Nedelec, P., Cammas, J.-P., Thouret, V., Athier, G., Cousin, J.-M., Legrand, C., Abonnel, C., Lecoeur, F., Cayez, G., and Marizy, C.: An improved infrared carbon monoxide analyser for routine measurements aboard commercial Airbus aircraft: technical validation and first scientific results of the MOZAIC III programme, Atmos. Chem. Phys., 3, 1551-1564, doi:10.5194/acp-3-15512003, 2003.

Neu, J. L. and Prather, M. J.: Toward a more physical representation of precipitation scavenging in global chemistry models: cloud overlap and ice physics and their impact on tropospheric ozone, Atmos. Chem. Phys., 12, 3289-3310, doi:10.5194/acp-12-32892012, 2012.

O’Connor, F. M., Johnson, C. E., Morgenstern, O., Abraham, N. L., Braesicke, P., Dalvi, M., Folberth, G. A., Sanderson, M. G., Telford, P. J., Voulgarakis, A., Young, P. J., Zeng, G., Collins, W. J., and Pyle, J. A.: Evaluation of the new UKCA climatecomposition model - Part 2: The Troposphere, Geosci. Model Dev., 7, 41-91, doi:10.5194/gmd-7-41-2014, 2014.

Olivier, J., Peters, J., Granier, C., Petron, G., Muller, J. F., and Wallens, S.: Present and future surface emissions of atmospheric compounds, POET report \#2, EU project EVK2-1999-00011, 2003

Ordóñez, C., Elguindi, N., Stein, O., Huijnen, V., Flemming, J., Inness, A., Flentje, H., Katragkou, E., Moinat, P., Peuch, V.-H., Segers, A., Thouret, V., Athier, G., van Weele, M., Zerefos, C. S., Cammas, J.-P., and Schultz, M. G.: Global model simulations of air pollution during the 2003 European heat wave, Atmos. Chem. Phys., 10, 789-815, doi:10.5194/acp-10-789-2010, 2010.

Ott, L. E., Pickering, K. E., Stenchikov, G. L., Allen, D. J., DeCaria, A. J., Ridley, B., Lin, R.-F., Lang, S., and Tao, W.-K.: Production of lightning NOx and its vertical distribution calculated from three-dimensional cloud-scale chemical transport model simulations, J. Geophys. Res., 115, D04301, doi:10.1029/2009JD011880, 2010.

Pickering, K. E., Wang, Y., Tao, W.-K., Price, C., and Müller, J.-F.: Vertical distributions of lightning NOx for use in regional and global chemical transport models, J. Geophys. Res., 103, 3120331216, doi:10.1029/98JD02651, 1998.

Platt, U.: Differential optical absorption spectroscopy (DOAS), in: Air Monitoring by Spectroscopic Techniques, Chem. Anal. Ser., 127, 27-84, 1994.

Pozzoli, L., Bey, I., Rast, J. S., Schultz, M. G., Stier, P., and Feichter, J.: Trace gas and aerosol interactions in the fully coupled model of aerosol-chemistry-climate ECHAM5-HAMMOZ, PART I: Model description and insights from the spring 2001 TRACE-P experiment, J. Geophys. Res., 113, D07308, doi:10.1029/2007JD009007, 2008.
Prather, M. and Ehhalt, D.: Atmospheric chemistry and greenhouse gases, in: Climate Change 2001: The Scientific Basis, edited by: Houghton, J. T., Ding, Y., Griggs, D. J., Noguer, M., van der Linden, P. J., Dai, X., Maskell, K., and Johnson, C. A., 239-287, Cambridge University Press, Cambridge, UK, 2001.

Prather, M. J., Holmes, C. D., and Hsu, J.: Reactive greenhouse gas scenarios: Systematic exploration of uncertainties and the role of atmospheric chemistry, Geophys. Res. Lett., 39, L09803, doi:10.1029/2012GL051440, 2012.

Price, C. and Rind, D.: A simple lightning parameterization for calculating global lightning distributions, J. Geophys. Res., 97, 9919-9933, 1992.

Price, C. and Rind, D.: What determines the cloud-to-ground fraction in thunderstorms?, Geophys Res. Lett., 20, 463-466, 1993.

Price, C., Penner, J., and Prather, M.: NOx from lightning 1. Global distributions based on lightning physics, J. Geophys. Res., 102 5929-5941, doi:10.1029/96JD03504, 1997.

Rast, S., Schultz, M. G., Bey, I., van Noije, T., Aghedo, A .M., Brasseur, G. P., Diehl, T., Esch, M., Ganzeveld, L., Kirchner, I., Kornblueh, L., Rhodin, A., Röckner, E., Schmidt, H., Schröder, S., Schulzweida, U., Stier, P., Thomas, K., and Walters, S.: Evaluation of the tropospheric chemistry general circulation model ECHAM5-MOZ and its application to the analysis of the chemical composition of the troposphere with an emphasis on the late RETRO period 1990-2000, Reports on Earth-System Science, 114, Max-Planck Institut fuer Meteorologie, Hamburg, 2014.

Redler, R., Valcke, S., and Ritzdorf, H.: OASIS4 - a coupling software for next generation earth system modelling, Geosci. Model Dev., 3, 87-104, doi:10.5194/gmd-3-87-2010, 2010.

Richter, A., Burrows, J. P., Nüß, H., Granier, C., Niemeier, U., Increase in tropospheric nitrogen dioxide over China observed from space, Nature, 437, 129-132, doi:10.1038/nature04092, 2005.

Richter, A., Begoin, M., Hilboll, A., and Burrows, J. P.: An improved NO2 retrieval for the GOME-2 satellite instrument, Atmos. Meas. Tech., 4, 1147-1159, doi:10.5194/amt-4-1147-2011, 2011.

Sander, R.: Compilation of Henry's Law Constants for Inorganic and Organic Species of Potential Importance in Environmental Chemistry, MPI for Chemistry Mainz, Germany, available at: http://www.henrys-law.org/ (last access: 29 March 2015), 1999.

Sander, S. P., Friedl, R. R., Golden, D. M., Kurylo, M. J., Moortgat, G. K., Keller-Rudek, H., Wine, P. H., Ravishankara, A. R., Kolb, C. E., Molina, M. J., Finlayson-Pitts, B. J., Huie, R. E., and Orkin, V. L.: Chemical Kinetics and Photochemical Data for Use in Atmospheric Studies, Evaluation Number 15, JPL Publication 06-02, Jet Propulsion Laboratory, Pasadena, California, 2006.

Sander, S. P., Abbatt, J. R., Burkholder, J. B., Friedl, R. R., Golden, D. M., Huie, R. E., Kolb, C. E., Kurylo, G., Moortgat, K., Orkin, V. L., and Wine, P. H.: Chemical kinetics and Photochemical Data for Use in Atmospheric studies, Evaluation No. 17, JPL Publication 10-6, Jet Propulsion Laboratory, Pasadena, 2011.

Savage, N. H., Agnew, P., Davis, L. S., Ordóñez, C., Thorpe, R., Johnson, C. E., O'Connor, F. M., and Dalvi, M.: Air quality modelling using the Met Office Unified Model (AQUM OS24-26): model description and initial evaluation, Geosci. Model Dev., 6, 353-372, doi:10.5194/gmd-6-353-2013, 2013. 
Schumann, U. and Huntrieser, H.: The global lightning-induced nitrogen oxides source, Atmos. Chem. Phys., 7, 3823-3907, doi:10.5194/acp-7-3823-2007, 2007.

Seinfeld, J. H. and Pandis, S. N.: Atmospheric Chemistry and Physics: From Air Pollution to Climate Change, 1st edition, J. Wiley, New York, 1998.

Shindell, D. T., Faluvegi, G., Stevenson, D. S., Krol, M. C., Emmons, L. K., Lamarque, J.-F., Pétron, G., Dentener, F. J., Ellingsen, K., Schultz, M. G., Wild, O., Amann, M., Atherton, C. S., Bergmann, D. J., Bey, I., Butler, T., Cofala, J., Collins, W. J., Derwent, R. G., Doherty, R. M., Drevet, J., Eskes, H. J., Fiore, A. M., Gauss, M., Hauglustaine, D. A., Horowitz, L. W., Isaksen, I. S. A., Lawrence, M. G., Montanaro, V., Müller, J.-F., Pitari, G., Prather, M. J., Pyle, J. A., Rast, S., Rodriguez, J. M., Sanderson, M. G., Savage, N. H., Strahan, S. E., Sudo, K., Szopa, S., Unger, N., van Noije, T. P. C., and Zeng, G.: Multi-model simulations of carbon monoxide: Comparison with observations and projected near-future changes. J. Geophys. Res., 111, D19306, doi:10.1029/2006JD007100, 2006.

Slingo, A.: A GCM parameterization for the shortwave radiative properties of water clouds, J. Atmos. Sci., 46, 1419-1427, 1989.

Steil, B., Dameris, M., Brühl, C., Crutzen, P. J., Grewe, V., Ponater, M., and Sausen, R.: Development of a chemistry module for GCMs: first results of a multiannual integration, Ann. Geophys., 16, 205-228, doi:10.1007/s00585-998-0205-8, 1998.

Stein, O., Flemming, J., Inness, A., Kaiser, J. W., and Schultz, M. G.: Global reactive gases forecasts and reanalysis in the MACC project, J. Int. Environ. Sci., 9, 57-70, doi:10.1080/1943815X.2012.696545, 2012.

Stein, O., Schultz, M. G., Bouarar, I., Clark, H., Huijnen, V., Gaudel, A., George, M., and Clerbaux, C.: On the wintertime low bias of Northern Hemisphere carbon monoxide found in global model simulations, Atmos. Chem. Phys., 14, 9295-9316, doi:10.5194/acp-14-9295-2014, 2014.

Stevenson, D. S. , Dentener, F. J., Schultz, M. G., Ellingsen, K., van Noije, T. P. C., Wild, O., Zeng, G., Amann, M., Atherton, C. S., Bell, N., Bergmann, D. J., Bey, I., Butler, T., Cofala, J., Collins, W. J., Derwent, R. G., Doherty, R. M.. Drevet, J., Eskes, H. J., Fiore, A. M., Gauss, M., Hauglustaine, D. A., Horowitz, L. W., Isaksen, I. S. A., Krol, M. C., Lamarque, J. F., Lawrence, M. G., Montanaro, V., Muller, J. F., Pitari, G., Prather, M. J., Pyle, J. A., Rast, S., Rodriguez, J. M., Sanderson, M. G., Savage, N. H., Shindell, D. T., Strahan, S. E., Sudo, K., and Szopa, S.: Multimodel ensemble simulations of present-day and near-future tropospheric ozone, J. Geophys. Res., 111, D08301, doi:10.1029/2005JD006338, 2006.

Temperton, C., Hortal, M., and Simmons, A.: A two-time-level semi-Lagrangian global spectral model, Q. J. R, 127, 111-127, 2001.

Tiedtke, M. A.: comprehensive mass flux scheme for cumulus parameterization in large-scale models, Mon. Weather. Rev., 117, 1779-1800, 1989.

Tilmes, S., Lamarque, J.-F., Emmons, L. K., Conley, A., Schultz, M. G., Saunois, M., Thouret, V., Thompson, A. M., Oltmans, S. J., Johnson, B., and Tarasick, D.: Technical Note: Ozonesonde climatology between 1995 and 2011: description, evaluation and applications, Atmos. Chem. Phys., 12, 74757497, doi:10.5194/acp-12-7475-2012, 2012.
Val Martin, M., Heald, C. L., and Arnold, S. R.: Coupling dry deposition to vegetation phenology in the Community Earth System Model: Implications for the simulation of surface O3, Geophys. Res. Lett., 41, 2988-2996, doi:10.1002/2014GL059651, 2014.

van Noije, T. P. C., Le Sager, P., Segers, A. J., van Velthoven, P. F. J., Krol, M. C., Hazeleger, W., Williams, A. G., and Chambers, S. D.: Simulation of tropospheric chemistry and aerosols with the climate model EC-Earth, Geosci. Model Dev., 7, 2435-2475, doi:10.5194/gmd-7-2435-2014, 2014.

von Blohn, N., Diehl, K., Mitra, S. K., and Borrmann, S.: Wind tunnel experiments on the retention of trace gases during riming: nitric acid, hydrochloric acid, and hydrogen peroxide, Atmos. Chem. Phys., 11, 11569-11579, doi:10.5194/acp-1111569-2011, 2011.

Voulgarakis, A., Naik, V., Lamarque, J.-F., Shindell, D. T., Young, P. J., Prather, M. J., Wild, O., Field, R. D., Bergmann, D., CameronSmith, P., Cionni, I., Collins, W. J., Dalsøren, S. B., Doherty, R. M., Eyring, V., Faluvegi, G., Folberth, G. A., Horowitz, L. W., Josse, B., MacKenzie, I. A., Nagashima, T., Plummer, D. A., Righi, M., Rumbold, S. T., Stevenson, D. S., Strode, S. A., Sudo, K., Szopa, S., and Zeng, G.: Analysis of present day and future $\mathrm{OH}$ and methane lifetime in the ACCMIP simulations, Atmos. Chem. Phys., 13, 2563-2587, doi:10.5194/acp-13-25632013, 2013.

Vrekoussis, M., Wittrock, F., Richter, A., and Burrows, J. P.: GOME-2 observations of oxygenated VOCs: what can we learn from the ratio glyoxal to formaldehyde on a global scale?, Atmos. Chem. Phys., 10, 10145-10160, doi:10.5194/acp-1010145-2010, 2010.

Wang, P., Stammes, P., van der A, R., Pinardi, G., and van Roozendael, M.: FRESCO+: an improved $\mathrm{O}_{2}$ A-band cloud retrieval algorithm for tropospheric trace gas retrievals, Atmos. Chem. Phys., 8, 6565-6576, doi:10.5194/acp-8-6565-2008, 2008.

Wesely, M. L.: Parameterization of Surface Resistances to Gaseous Dry Deposition in Regional-Scale Numerical Models, Atmos. Environ., 23, 1293-1304, 1989.

Williams, J. E., Strunk, A., Huijnen, V., and van Weele, M.: The application of the Modified Band Approach for the calculation of on-line photodissociation rate constants in TM5: implications for oxidative capacity, Geosci. Model Dev., 5, 15-35, doi:10.5194/gmd-5-15-2012, 2012.

Williams, J. E., van Velthoven, P. F. J., and Brenninkmeijer, C. A. M.: Quantifying the uncertainty in simulating global tropospheric composition due to the variability in global emission estimates of Biogenic Volatile Organic Compounds, Atmos. Chem. Phys., 13, 2857-2891, doi:10.5194/acp-13-2857-2013, 2013.

Wittrock, F., Richter, A., Oetjen, H., Burrows, J. P., Kanakidou, M., Myriokefalitakis, S., Volkamer, R., Beirle, S., Platt, U., and Wagner, T.: Simultaneous global observations of glyoxal and formaldehyde from space, Geophys. Res. Lett., 33, L16804, doi:10.1029/2006GL026310, 2006.

WMO: WMO Global Atmosphere Watch (GAW) Strategic Plan: 2008-2015, World Meteorological Organization, Geneva, Switzerland, 2007.

Yarwood, G., Rao, S., Yocke, M., and Whitten, G.: Updates to the carbon bond chemical mechanism: CB05. Final report to the US EPA, EPA Report Number: RT-0400675, available at: www.camx.com (last access: 1 July 2014), 2005. 
Young, P. J., Archibald, A. T., Bowman, K. W., Lamarque, J.-F., Naik, V., Stevenson, D. S., Tilmes, S., Voulgarakis, A., Wild, O., Bergmann, D., Cameron-Smith, P., Cionni, I., Collins, W. J., Dalsøren, S. B., Doherty, R. M., Eyring, V., Faluvegi, G., Horowitz, L. W., Josse, B., Lee, Y. H., MacKenzie, I. A., Nagashima, T., Plummer, D. A., Righi, M., Rumbold, S. T., Skeie, R. B., Shindell, D. T., Strode, S. A., Sudo, K., Szopa, S., and Zeng, G.: Preindustrial to end 21st century projections of tropospheric ozone from the Atmospheric Chemistry and Climate Model Intercomparison Project (ACCMIP), Atmos. Chem. Phys., 13, 20632090, doi:10.5194/acp-13-2063-2013, 2013.

Zaveri, R. A. and Peters, L. K.: A new lumped structure photochemical mechanism for large-scale applications, J. Geophys. Res., 104, 30387-30415, doi:10.1029/1999JD900876, 1999.
Zdunkowski, W. G., Welsch, R. M., and Kord, G. J.: An investigation of the structure of typical 2-stream methods for the calculation of solar fluxes and heating rates in clouds, Contrib. Atmos. Phys., 53, 215-238, 1980.

Zhang, L., Brook, J. R., and Vet, R.: A revised parameterization for gaseous dry deposition in air-quality models, Atmos. Chem. Phys., 3, 2067-2082, doi:10.5194/acp-3-2067-2003, 2003.

Zhang, Y., Karamchandani, P., Glotfelty, T., Streets, D. G., Grell, G., Nenes, A., Yu, F., and Bennartz, R.: Development and initial application of the global-through-urban weather research and forecasting model with chemistry (GU-WRF/Chem), J. Geophys. Res., 117, D20206, doi:10.1029/2012JD017966, 2012. 